\title{
How History Can Inform Practice in Modern U.S. Competition Policy
}

\author{
Timothy J. Muris \\ Chairman \\ FEDERAL TRADE COMMISSION \\ 600 Pennsylvania Ave., NW \\ Washington, D.C. 20580
}

\begin{abstract}
The first section of the paper reviews patterns in modern federal antitrust enforcement. Some commentators have theorized that modern enforcement has swung back and forth between extremes in response to changes in political leadership in the federal antitrust agencies and that there is little continuity of viewpoints between the extremes of the arc. Using enforcement data from 1961 through 2004, the paper reveals that the assumptions underlying these theories are faulty. In reality, there was a seismic shift in antitrust theory in the 1960s and early 1970s that courts began to adopt in the mid 1970s. The paper demonstrates that while antitrust agencies lagged in adjusting to these developments, they eventually changed in the 1980s to a new course on which they have basically remained, with relatively minor adjustments. The enforcement that followed built upon the contributions of earlier periods; the cumulative effect was a bipartisan and widely shared vision of appropriate policy.
\end{abstract}

The second section of the paper derives lessons about policymaking from antitrust enforcement experience in recent decades. Developments in economic learning and changes in industrial conditions or technology are important guideposts to ensure that competition policy does not veer off into ineffective or harmful backwaters. Despite evolving economic scholarship that undermined the theoretical support for certain types of cases, the Federal Trade Commission (FTC) in the 1970s continued on a misguided course regarding dominant firm misconduct, vertical distribution restraints, and the treatment of merger efficiencies. In addition to these weaknesses in enforcement theories, the second section of the paper also identifies administrative errors by the FTC during this period. The agency took on many more complex cases than it could execute well, even if those cases had not also had doctrinal difficulties.

The paper concludes by suggesting practical approaches that government agencies, and, more specifically, the FTC should take to improve the quality of competition policy. It argues that agencies need to reassess their status continually by analyzing the effects of previous actions and making adjustments, if necessary, and by keeping abreast of developments in theory and evidence. Agencies must also engage in what can be called "competition policy research and development" to increase their intellectual capital and inform the competition policy community about important developments. Finally, they must evaluate the potential long-term institutional impact of their actions and ensure that they are not diminishing their future capabilities.

Keywords: Antitrust, Federal Trade Commission, Economic History

JEL Classification: K21, L 4, L 44, N42 


\title{
How History Can Inform Practice in Modern U.S. Competition Policy
}

\author{
by \\ Timothy J. Muris ${ }^{1}$
}

\section{Introduction}

Antitrust has a wide interdisciplinary attraction. While the connection to economics is obvious, antitrust also has appeal to other areas of study. For example, antitrust decisions often resemble historical narratives. In technical terms, Standard Oil $^{2}$ and Socony-Vacuum ${ }^{3}$ discuss the rule of reason and per se illegality, yet they also tell the history of the petroleum industry. These legal landmarks offer perspectives upon our nation's economy and regulatory institutions, both past and present.

Antitrust history extends beyond the development of individual commercial sectors and regulatory institutions. The history of federal competition policy can inform future government enforcement practice in at least two key respects. ${ }^{4}$ The first is to provide an accurate view of

1 Chairman, Federal Trade Commission. The views here are mine, not those of any other Commissioner. I would like to thank William E. Kovacic and Maureen K. Ohlhausen for their help in preparing this paper. I would also like to thank Thomas Krattenmaker for his helpful comments.

$2 \quad$ Standard Oil Co. v. United States, 221 U.S. 1 (1911).

$3 \quad$ United States v. Socony-Vacuum Oil Co., 310 U.S. 150 (1940).

$4 \quad$ Applications of historical research to modern enforcement policy form the core of three recent papers by FTC officials. In 2002, Commissioner Thomas Leary evaluated the development of federal merger enforcement policy and the treatment of efficiency arguments in merger analysis. Thomas B. Leary, The Essential Stability of Merger Policy in the United States, 70 ANTITRUST L.J. 105 (2002); Thomas B. Leary, Commissioner, Federal Trade Commission, 
how the Department of Justice (DOJ) and the Federal Trade Commission (FTC) have exercised their authority. An accurate positive understanding of yesterday's enforcement trends helps formulate normative proposals about how the agencies should act tomorrow. The second, closely-related contribution of historical analysis involves the evaluation and interpretation of past experience. Beyond knowing what the enforcement agencies did, it is important to understand why they made specific policy choices and why those initiatives succeeded or failed.

This paper reviews modern federal enforcement policy for its lessons about how present and future competition agencies should exercise their authority. In doing so, it will synthesize insights from the existing literature, add additional analysis of history, and discuss noteworthy implications of modern U.S. experience for making competition policy in the years ahead. This paper has three specific aims. The first is to describe how federal enforcement activity has evolved since 1961. In documenting adjustments in the mix of enforcement outputs, it will emphasize the "essential stability" of U.S. competition policy since 1981. The second goal is to assess why enforcement patterns evolved as they have - to go beyond a simple recital of enforcement activity to identify strengths and weaknesses in agency decision making. The third objective is to suggest how modern experience can inform future practice in making competition policy. A careful assessment of the past provides a richer understanding of how government agencies should act.

To accomplish these goals, the first section of this paper reviews patterns in modern

Efficiencies and Antitrust: A Story of Ongoing Evolution, Remarks Before the ABA Section of Antitrust Law 2002 Fall Forum (Nov. 8, 2002), available at $<$ http://www.ftc.gov/speeches/leary/efficienciesandantitrust.htm>. In 2003, FTC General Counsel, William Kovacic, completed a study of how DOJ and FTC antitrust enforcement norms have evolved since 1960. William E. Kovacic, The Modern Evolution of U.S. Competition Policy Enforcement Norms, 71 ANTITRUST L.J. 377 (2003). 
federal antitrust enforcement. Some commentators have theorized that modern federal antitrust enforcement has swung back and forth between extremes in response to changes in political leadership in the federal antitrust agencies. These theories hold that shifts in leadership cause sharp swings in the opposite enforcement direction and that there is little continuity of viewpoints between the extremes of the arc. Using enforcement data from 1961 through 2004, the paper reveals that the assumptions underlying these theories are faulty. In reality, there was a seismic shift in antitrust theory in the 1960s and early 1970s that courts began to adopt in the mid 1970s. The paper demonstrates that while antitrust agencies lagged in adjusting to these developments, they eventually changed in the 1980s to a new course on which they have basically remained, with relatively minor adjustments. The enforcement that followed built upon the contributions of earlier periods and the cumulative effect was a bipartisan and widely shared vision of appropriate policy.

The second section of the paper derives lessons about policymaking from antitrust enforcement experience in recent decades. Developments in economic learning and changes in industrial conditions or technology are important guideposts to ensure that competition policy does not veer off into ineffective or harmful backwaters. The paper examines enforcement initiatives based on dominant firm misconduct, which sought structural remedies to reduce the market shares of dominant firms in a number of industries. Despite evolving economic scholarship that undermined the theoretical support for this theory, the FTC in the 1970s continued this agenda. The paper charts the FTC's similar misguided course in the areas of vertical distribution restraints and merger efficiencies. In addition to these weaknesses in enforcement theories, the second section of the paper also identifies administrative errors by the FTC during this period. The agency took on many more complex cases than it could execute 
well, even if those cases had not also had doctrinal difficulties.

The third part of the paper suggests practical approaches that government agencies, and, more specifically, the FTC should take to improve the quality of competition policy. It argues that agencies need to reassess their status continually by analyzing the effects of previous actions and making adjustments, if necessary, and by keeping abreast of developments in theory and evidence. Agencies must also engage in what can be called "competition policy research and development" to increase their intellectual capital and inform the competition policy community about important developments. Finally, they must evaluate the potential long-term institutional impact of their actions and ensure that they are not diminishing their future capabilities.

\section{The Evolution of Federal Antitrust Enforcement: 1961 through 2004}

\section{A. The Pendulum Narrative}

A change in administration and the appointment of new leaders to the federal enforcement agencies routinely inspire discussion about the future of antitrust policy and the start of a Republican majority at the FTC in June 2001 was no exception. Despite statements that competition initiatives at the Commission under a new chairman would feature substantial continuity with the program of the previous Democratic chairman of the FTC, Robert Pitofsky, ${ }^{5}$ antitrust commentors reacted either with disbelief that antitrust enforcement would continue ${ }^{6}$ or

5 Timothy J. Muris, Robert Pitofsky: Public Servant and Scholar, 52 CASE W. RES. L. Rev. 25 (2001); Timothy J. Muris, Chairman, Federal Trade Commission, Antitrust Enforcement at the Federal Trade Commission: In a Word - Continuity, Remarks Before the American Bar Association Antitrust Section Annual Meeting, Chicago, Illinois (Aug. 7, 2001), available at $<$ http://www.ftc.gov/speeches/muris/murisaba.htm $>$.

$6 \quad$ "You've probably never heard of Charles James or Tim Muris. Maybe not even Michael Powell. ... Together they herald a radical shift in the enforcement of America's antitrust laws: Under the Bush administration, there may not be any." John B. Judis, Trust Walk, THE NEW REPUBLIC ONLINE, June 11, 2001 (emphasis added), available at 
with concern that there would be no change. ${ }^{7}$ Both perspectives are intriguing. Why did some commentators pose the prospect that the FTC would cease antitrust enforcement or "abandon the field"? Why did others react with dismay about continuing the competition program of the Clinton Administration?

Each expression of alarm reflects, in its own way, uncritical acceptance of what observers have called the pendulum narrative of modern federal antitrust enforcement. The pendulum narrative classifies the last 40 years of DOJ and FTC enforcement in three phases: Too active in the 1960s and 1970s, too passive in the 1980s, and properly moderate in the 1990s. Put in terms that Goldilocks made famous, antitrust enforcement goes from too hot, to too cold, to just right.

Embedded in the pendulum narrative are three assumptions that explain the reactions to a prediction of continuity. One is that change in the ideology of leadership in the federal agencies mainly drives swings from one period to another. This view makes competition policy extremely sensitive to presidential appointments. The second assumption is that the Reagan administration laid waste to antitrust enforcement. ${ }^{8}$ This view predicts that anyone with a hand in the Reagan program would be inclined to extinguish antitrust enforcement. The third

<http://www.thenewrepublic.com/061101/judis060001.htm>. See also Albert A. Foer, Antitrust in Peril, Rutland Herald Daily, June 20, 2001 ("State attorneys general are prepared to expand the consumer watchdog if the FTC and the Justice Department's Antitrust Division abandon the field.") (emphasis added), available at <http://www.antitrustinstitute.org/recent/128.cfm>.

$7 \quad$ George Bittlingmayer, The Antitrust Emperor's Clothes, 25 REGULATION 46 (Fall 2002) ("Little has changed," this commentator noted. "The antitrust experts may be having fun, but the clothes they have draped on the emperor are threadbare at best.")

8 Commentators who accept the basic premises of the pendulum narrative vary in their views about the degree and effects of the retrenchment in the 1980s. For example, Professor Bittlingmayer applauds the Reagan administration's efforts to redefine the zone of enforcement, but he concludes that the Reagan antitrust agencies did not press the realignment aggressively enough. See id. at 48. 
assumption is that enforcement policy in the 1990s displayed little connection to enforcement policy in the 1980s, with the federal agencies' programs in the 1990s significantly departing from 1980s practice.

These assumptions explain the responses to the continuity prediction. If one believes that U.S. competition policy is prone to dramatic swings in activity, and that Reagan-era policy was an aberrational, inexcusably permissive departure from sensible enforcement, it follows that the appointment by a Republican president of an FTC chairman who helped shape Reagan-era policies might foreshadow the end of the Commission's antitrust activity. ${ }^{9}$ If one believes that enforcement policy takes shape in watertight compartments defined by each administration without significant links to or contributions from its predecessors, then the Clinton FTC retained little of the policies of the Reagan and first Bush administrations. In this framework, it is reasonable to believe that no one who conceived or endorsed the Reagan antitrust program could embrace so much of the Clinton antitrust agenda.

Each of these assumptions is faulty. Because the Goldilocks story depends on all of them, it is bankrupt for interpreting the development of modern competition policy. The balance of this section shows that modern experience does not feature dramatic, mechanistic swings in antitrust enforcement across periods from 1961 through 2000. Instead, there has been a paradigm shift in antitrust. The key phase of the transformation, led mainly by the academy and the courts, took place with the absorption of Chicago School perspectives into the mainstream of antitrust policy in the 1970 s and 1980s. ${ }^{10}$ Although the government agencies were the last to get

$9 \quad$ The author was Director of the FTC's Bureau of Competition from 1983 to 1985.

10 See Terry Calvani \& Michael L. Sibarium, Antitrust Today: Maturity or Decline, 35 ANTITRUST BULl. 123, 174 (1990) (concluding that modern antitrust law's "most significant 
the message, even the agencies took some steps before the 1980s to begin developing many of the sensible policies of today. There was a dramatic departure in 1981 from much of previous government policy, but enforcement across eras displays significant degrees of cumulative development. Closer to the present, enforcement in the 1990s reveals considerable similarity to norms endorsed in the 1980s. Indeed, this similarity caused Ralph Nader to observe during the 2000 presidential campaign that "[b]oth parties are terrible on antitrust." ${ }^{11}$ The elements of continuity and the institutional forces that account for the continuity explain why the U.S. competition policy system has escaped the mistakes of its past as well as built on prior successes.

\section{B. Federal Enforcement Activity Reconsidered: 1961-2003}

A common approach to evaluating federal competition policymaking is to examine the filing of new cases. This section examines enforcement trends over the past four decades. As a preliminary matter, one must recognize that the commencement of enforcement matters provides a rough, but highly imperfect, impression of agency activity. Even if one assumes that case filings are a suitable proxy for the quality of enforcement, many difficult methodological issues confront the identification and classification of cases. For example, many complaints or

changes have been in the case law, influenced by work done in the academy in the fields of law and industrial organization economics, much of which predates the Reagan era"); William E. Kovacic \& Carl Shapiro, Antitrust Policy: A Century of Economic and Legal Thinking, $14 \mathrm{~J}$. ECON. PERSPECTIVES 43, 52-53 (2000) (discussing influence of Chicago School perspectives on antitrust jurisprudence in 1970s).

11 Ralph Nader, CNN Burden of Proof, Aug. 9, 2000, Transcript No. 00080900V12, at 6. Nader continued:

Look, we have Boeing now, one aircraft company, manufacturer after the McDonnell Douglas merger. They've allowed mergers under Clinton of the giant HMOs, the giant hospital chains, the giant telecommunication companies. Their one bright light is ... Microsoft.

Id. 
settlements represent the culmination in one administration of activity (such as the initiation or pursuit of an investigation) that began in previous administrations. Moreover, raw case counts also say little about the doctrinal or economic significance of specific matters, or their actual market impact. ${ }^{12}$

This is not to say that case counts lack value. Indeed, as we will see, an accurate portrayal of past case activity can reveal significant shifts in policy. The discussion below examines trends in enforcement concerning both nonmerger and merger matters. The data focus on FTC enforcement, with considerable discussion of DOJ activity.

\section{Federal Nonmerger Antitrust Enforcement: 1961-2000}

Table 1 provides an aggregate overview of FTC nonmerger enforcement activity by presidential administration from 1961 through 2000:

Table 1: Average Number of FTC Antitrust Nonmerger Cases Per Calendar Year - 1961 through $2003^{13}$

12 Moreover, a case-centric approach does not count the publication of influential FTC studies, the preparation of reports that present the results of workshops or hearings concerning significant competition policy issues, or advocacy that discourages a legislature or regulatory authority from needlessly restricting competition. See, e.g., Federal Trade Commission, Generic Drug Entry Prior to Patent Expiration: An FTC Study (July 2002), available at $\langle$ http://www.ftc.gov/os/2002/07/genericdrugstudy.pdf $>$; Federal Trade Commission, To Promote Innovation: The Proper Balance of Competition and Patent Law and Policy (Oct. 2003), available at $<$ http://www.ftc.gov/os/2003/10/innovationrpt.pdf>; Federal Trade Commission, Office of Policy Planning, Report of the State Action Task Force(Sept. 2003),

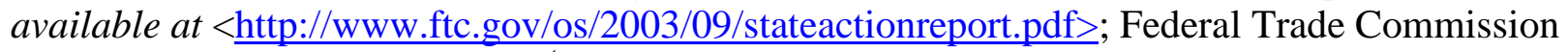
Staff Report, Anticipating the $21^{\text {st }}$ Century: Competition Policy in the New High-Tech, Global Marketplace (May 1996), available at $<$ http://www.ftc.gov/opp/global/report/gc_v1.pdf $>$; Federal Trade Commission, A Positive Agenda for Consumers: The FTC Year in Review 21-22 (Apr. 2003) [hereinafter 2003 Year in Review] (describing FTC advocacy filings involving the unauthorized practice of law and proposals to restrict the sale of replacement contact lenses).

13 Table 1 is derived from data collected from the $\mathrm{CCH}$ Trade Regulation Reporter. The averages are rounded to the nearest tenth of a case. "HR" means horizontal restraints, "VR" 


$\begin{array}{lllll}\text { President } & \text { HR } & \text { VR } & \text { Dominance } & \text { RP } \\ \text { Kennedy/Johnson (1961-68) } & 2.6 & 2.4 & 1 & 64.7 \\ \text { Nixon/Ford (1968-1976) } & 1.5 & 7.4 & 1.2 & 5.1 \\ \text { Carter (1977-1980) } & 5.5 & 5.8 & 0.7 & 2 \\ \text { Reagan (1981-1988) } & 7 & 0.6 & 0.2 & 0.6 \\ \text { Bush I (1989-1992) } & 6.2 & 1 & 0 & 0 \\ \text { Clinton (1993-2000) } & 7.6 & 1 & 0.5 & 0.1 \\ \text { Bush II (2001-2003) } & 9.6 & 0 & 1.3 & 0\end{array}$

Tables 2 and 3 provide a point of comparison for FTC activity and a fuller perspective on government enforcement by adding data for DOJ for matters involving monopolization or attempted monopolization and vertical contractual restraints, respectively. Table 4 provides data by decade on DOJ criminal cases.

Table 2: Average Number of DOJ and FTC Monopolization and Attempted Monopolization Cases Per Calendar Year - 1961 to $2003{ }^{14}$

$\begin{array}{llll}\text { President } & \text { DOJ } & \text { FTC } & \text { Total Federal Average } \\ \text { Kennedy/Johnson (1961-1968) } & 1.6 & 1 & 2.6 \\ \text { Nixon/Ford (1969-1976) } & 2.1 & 1.2 & 3.3 \\ \text { Carter (1977-1980) } & 0.5 & 0.7 & 1.2 \\ \text { Reagan (1981-1988) } & 0.2 & 0.2 & 0.4 \\ \text { Bush I (1989-1992) } & 0 & 0 & 0 \\ \text { Clinton (1993-2000) } & 0.9 & 0.5 & 1.4 \\ \text { Bush II (2001-2003) } & 0 & 1.3 & 1.3\end{array}$

Table 3: Average Number of DOJ and FTC Vertical Restraints Cases Per Calendar Year1961 through $2003^{15}$

means vertical restraints, and "RP" stands for Robinson Patman.

14 Table 2 is derived from data collected from the $\mathrm{CCH}$ Trade Regulation Reporter. The averages are rounded to the nearest tenth of a case.

15 Table 3 is derived from data collected from the $\mathrm{CCH}$ Trade Regulation Reporter. The averages are rounded to the nearest tenth of a case. 


$\begin{array}{llll}\text { President } & \text { DOJ } & \text { FTC } & \text { Total Federal Cases/Year } \\ \text { Kennedy/Johnson (1961-1968) } & 4 & 2.4 & 6.4 \\ \text { Nixon/Ford (1969-1976) } & 6.5 & 7.4 & 13.9 \\ \text { Carter (1977-1980) } & 1.2 & 5.8 & 7 \\ \text { Reagan (1981-88) } & 0 & 0.6 & 0.6 \\ \text { Bush I (1989-1992) } & 0 & 1 & 1 \\ \text { Clinton (1993-2000) } & 1 & 1 & 2 \\ \text { Bush II (2001-2003) } & 0 & 0 & 0\end{array}$

Table 4: DOJ Criminal Antitrust Cases Average Per Calendar Year-1961 to $2002^{16}$

\section{Decade}

1961 to 1970

1971 to 1980

1981 to 1990

1991 to 2000

2001 to $2003^{17}$

\section{Average Number of Cases/Year}

12.8

8.1

80.2

62.2

39.3

The enforcement data from 1961 through 2003 present a more complex mosaic of enforcement activity than the pendulum narrative suggests. Rather than featuring a single pattern consisting of dramatic swings from one level of enforcement to another, the data show four different patterns. First, as Table 1 reveals, Robinson-Patman enforcement declines in each decade after the 1960s. By the 1970s, the DOJ ceded all RP enforcement to the FTC, ${ }^{18}$ which

16 Table 4 is derived from workload statistics provided by the Antitrust Division.

17 The decline in average number of cases in 2001 to 2003 is likely the result of a precipitous decline in grand jury investigations initiated in the mid to late 1990s. Initiations of grand jury investigations in the years 1991-1993 averaged 49 per year; in the remaining years of the 1990s, the average was 27 per year; which includes 1999 when DOJ initiated only 19 such investigations. Because a grand jury investigation is a prerequisite to a criminal indictment, the decline in such investigations in the mid to late 1990s necessarily led to a decline in the subsequent initiations of criminal antitrust cases in 2001 and 2002. DOJ, however, has recently reversed this trend and, in 2003, initiated 48 grand jury investigations.

18 See Thomas E. Kauper, The Justice Department and the Antitrust Laws: Law Enforcer or Regulator?, 35 ANTITRUST BULL. 83, 99 (1990) (during Kauper's tenure as head of the Antitrust Division in the 1970s, DOJ "used its understanding with the FTC that the latter would be responsible for government enforcement of the Robinson-Patman Act to avoid any 
pursued numerous matters throughout that decade. Following harsh criticism by the 1969 American Bar Association study of the FTC's RP program ${ }^{19}$ and the appointment in 1970 of the study's chair (Miles Kirkpatrick) to head the agency, the Commission de-emphasized RP enforcement. This programmatic adjustment, which dropped the number of RP matters to an average of two per year by the end of the 1970s, produced a lasting change.

Second, Tables 1 and 4 reveal that horizontal restraints enforcement, including DOJ prosecution of criminal cases, expanded. With some variation in the number of prosecutions after 1980, horizontal cases became the centerpiece of nonmerger federal government enforcement. New and enduring focal points of civil enforcement activity included the professions and their trade associations. ${ }^{20}$ Beginning in the mid- to late-1970s, DOJ gave primacy to the criminal prosecution of supplier collusion and expanded this effort from the early 1980s onward. Although criminal prosecutions decreased somewhat in number in the 1990s compared to the 1980 s, DOJ achieved a dramatic increase in penalties recovered. ${ }^{21}$

Third, vertical distribution restraints cases (see Table 3) were a prominent part of

involvement under a statute it thought economically unwise").

19 Commission to Study the FTC, American Bar Association, Report of the Commission to Study the Federal Trade Commission 67-68 (Sept. 15, 1969) (recommending that FTC "initiate a study and appraisal of the compatibility of the Robinson-Patman Act and its current interpretations to the attainment of antitrust objectives" and, during this appraisal, limit the agency's enforcement of the Act to "instances in which injury to competition is clear").

20 Pivotal developments in this progression included cases initiated in the 1970s by the DOJ and the FTC, respectively, against the National Society of Professional Engineers and the American Medical Association. See National Soc'y of Professional Eng'rs v. United States, 435 U.S. 679 (1978); American Med. Ass'n v. FTC, 638 F.2d 443 (2d Cir. 1980), aff'd per curiam by an equally divided Court, 455 U.S. 676 (1982).

21 See Gary R. Spratling, Detection and Deterrence: Rewarding Informants for Reporting Violations, 69 GEO. WASH. L. REV. 798 (2001) (reviewing increase in DOJ antitrust criminal enforcement recoveries in 1990s). 
government enforcement through the 1970s, especially at the FTC. During the Reagan administration, vertical restraints activity ceased, save for the entry by the FTC of a small number of consent orders in matters for which investigations largely had been completed during the Carter administration. From 1989 through 1992, the DOJ brought no vertical restraints matters, while the FTC initiated one case per year. During the Clinton administration, the DOJ and the FTC each issued an average of one vertical restraints case per year.

The rate of vertical restraints activity during the Clinton administration exceeded enforcement levels during the Reagan administration and the Bush I program at the DOJ. Nonetheless, the average number of total DOJ and FTC cases per year (two) from 1993 through 2000 paled in comparison to levels of enforcement that prevailed before 1981. Total federal vertical restraints cases averaged roughly 6.4 per year in the Kennedy/Johnson era, nearly 14 per year in the Nixon/Ford administrations, and 7 per year during the Carter presidency. As will be discussed below, ${ }^{22}$ the failure of the government agencies before 1981 to absorb the new economic learning toward these cases, even after the Supreme Court in Sylvania in 1977 had repudiated Schwinn's per se ban on non-price restraints, stands out as one of the most significant (and avoidable) institutional failings of federal enforcement of that period.

Finally, the data in Table 2 indicate that enforcement involving dominant firm misconduct peaked in the Nixon/Ford years. As discussed below, ${ }^{23}$ these matters had serious implications for federal enforcement, and U.S. competition policy, that mere case counts do not adequately portray. The number of DOJ and FTC dominant firm matters declined in the 1980s. Dominant firm prosecutions increased in the Clinton years, but to levels well below those

22 See infra Section II.A.2. 
prevailing before 1981. Section 2 cases have continued in the Bush II era, at least at the FTC.

As the foregoing observations suggest, the pendulum narrative is flawed even when one focuses on simple case counts. In the nonmerger area, the Clinton years continued the ascent of horizontal restraints that began in the mid-1970s and accelerated under Bill Baxter and Jim Miller in the 1980s. ${ }^{24}$ At the FTC, the decline in RP enforcement began in the 1970s and continued through the subsequent decades. No one is likely to interpret the FTC's decision to accept a consent agreement in 2000 in the McCormick spice case,${ }^{25}$ a much debated matter concluded with a 3-2 vote, as presaging a new era of expansive RP enforcement.

Vertical distribution cases did change in the enforcement mix from 1981 to 2000 - from barely existent (the settlement of a few matters in the 1980s), to one case per year at the FTC during Bush I, and an average of one case per year at both the DOJ and the FTC in the Clinton administration. ${ }^{26}$ In light of the demanding requirements that Sylvania, Monsanto,${ }^{27}$ Sharp,${ }^{28}$ and

23 See infra Section II.A.1.

24 See Kovacic, Modern Evolution, supra note 4, at 415 (discussing increasing prominence given to horizontal restraints enforcement by DOJ and FTC from 1970s through 1990s).

25 McCormick \& Co., [FTC Complaints \& Orders 1997-2001 Transfer Binder] Trade Reg. Rep. (CCH) II 24,711 (2000).

26 During the Bush II administration, neither the DOJ nor the FTC have issued a vertical restraints case. Vertical issues, more generally, have been the subject of non-vertical restraints cases, including FTC challenges to vertical mergers and to dominant firm exclusionary conduct having vertical dimensions. See, e.g., Federal Trade Commission, 2003 Year in Review, at 8 (discussing FTC's analysis of vertical issues in deciding to challenge Cytyc/Digene merger).

$27 \quad$ Monsanto Co. v. Spray-Rite Service Corp., 465 U.S. 752 (1984).

28 Business Electronics Corp. v. Sharp Electronics Corp., 485 U.S. 717 (1988). 
Khan $^{29}$ have imposed on plaintiffs seeking to sustain distribution practices claims, vertical cases are bound to have only a diminished place in any future enforcement program. ${ }^{30}$ Moreover, many scholars have urged caution in addressing such matters. ${ }^{31}$ A number of Clinton administration vertical cases reflected these concerns, sometimes by hesitating to apply per se approaches $^{32}$ and sometimes by focusing on vertical restraints that were alleged to have caused

State Oil Co. v. Khan, 522 U.S. 3 (1997).

$30 \quad$ Reflecting in 1987 on the Reagan administration's reduction of vertical restraints enforcement, Sanford Litvack observed that the shift in judicial doctrine governing distribution practices had led him to doubt "that government enforcement is going to change materially" in the future. Sanford M. Litvack, The Future Viability of the Current Antitrust Treatment of Vertical Restraints, 75 CAL. L. REV. 955, 956 (1987). Litvack had led the Antitrust Division in the last years of the Carter administration and had been the last Assistant Attorney General to bring a criminal case against resale price maintenance.

31 See Andrew I. Gavil et al., Antitrust Law in Perspective: Cases, ConcePtS AND PROBlems In COMPETITION POLICY 373-80 (2002) (reviewing economic arguments for and against per se ban on minimum resale price maintenance; concluding that "[u]ltimately . . . support for the per se rule may rest more on ideology - suspicions regarding the motivations of businesses and the vulnerability of consumers - than on any clear, articulate and empirically based economic theory"); see also Donald Turner, The Durability, Relevance, and Future of American Antitrust Policy, 75 CAL. L. REV. 797, 804 (1987) (proposing that courts "create one or perhaps more exceptions to the per se rule regarding minimum resale price maintenance"); Robert Pitofsky, In Defense of Discounters: The No-Frills Case For a Per Se Rule Against Vertical Price Fixing, 71 GEO. L.J. 1487, 1495 (1983) (proposing recognition of exceptions from per se condemnation for minimum RPM agreements involving new entrants, new products, and failing companies).

32 In September 2000, the FTC entered a consent order settling charges that the Minimum Advertised Pricing (MAP) policies of five music companies violated Section 5 of the FTC Act. In a statement explaining the proposed consent orders in May 2000, the Commission "considered carefully whether the anticompetitive vertical restraints should be evaluated under a per se rule or a rule of reason." The Commission decided to apply the rule of reason and found the arrangements unlawful. Statement of Chairman Robert Pitofsky and Commissioners Sheila F. Anthony, Mozelle W. Thompson, Orson Swindle, and Thomas B. Leary, Time Warner Inc., et al. (May 10, 2000), available at <http://www.ftc.gov/os/2000/05/cdstatement.htm>. 
horizontal problems that most observers would regard as reasonable subjects for scrutiny. ${ }^{33}$

Like vertical cases, dominant firm cases fell significantly during the Reagan and Bush I administrations. Unlike vertical distribution matters, the Reagan agencies supported selective Section 2 enforcement. The relatively limited place of these matters in the entire federal enforcement mix in the 1980s ought not obscure the value of DOJ's devising and implementing the AT\&T divestiture, one of the government's few successes among the roster of ambitious Section 2 cases that began in the late 1960s and continued throughout the 1970s. Moreover, American Airlines $^{34}$ had a significant impact on subsequent attempted monopolization and horizontal restraints policy, and the concept explored in $A M E R C O,{ }^{35}$ that certain abuses of government processes should be treated as unlawful exclusion, has great utility.

The Clinton administration increased dominant firm prosecutions, but in numbers well below those prevailing in the 1960s and 1970s. More important, the Clinton cases were not based on the powerful structural presumptions that had animated enforcement in the deconcentration cases of the late 1960s and the 1970s. The Clinton cases generally displayed a substantive orientation better attuned to the analytical and institutional concerns that various commentators and Reagan enforcement officials had raised about earlier Section 2 enforcement

33 See, e.g., Waterous Co., 122 F.T.C. 414 (1996) (entering consent order involving exclusive dealing in the sale and marketing of fire pumps); Hale Prods., 122 F.T.C. 401 (1996) (same). In accepting the consent orders in Waterous and Hale Products, the Commission majority relied heavily on the theory that the challenged exclusive dealing arrangements facilitated an allocation of customers between the two pump producers.

$34 \quad$ United States v. American Airlines, Inc., 743 F.2d 1114 (5 ${ }^{\text {th }}$ Cir. 1984).

$35 \quad$ AMERCO, 109 F.T.C. 135 (1987). 
initiatives. Although some of the Clinton cases were controversial ${ }^{36}$ and involved difficult issues of law and policy, ${ }^{37}$ the FTC's recent cases indicate bipartisan support for the principle that Section 2 is a valuable ingredient of federal enforcement policy, albeit one that will be used sparingly. ${ }^{38}$

\section{A Closer Look at the Pendulum Narrative: 1981 to the Present}

Proponents of the pendulum theory might argue that the enforcement agenda of the 1970s was an anomaly and that once the antitrust agencies adapted to the seismic changes in the academic and legal landscape, enforcers still swung back and forth based on the party in power. To test this version of the pendulum theory, we analyze enforcement since 1981, considering nonmerger cases first, then merger enforcement. We will see that the pendulum theory remains unsupported. There are observable variations in enforcement, but these differences cross party lines and appear to reflect either differences between the FTC and DOJ or the preferences of the various enforcement officials.

\section{(a.) Nonmerger Cases}

Since 1981, there have been six terms of office for four different Presidents. Tables 5 through 8 present enforcement officials for the 11 heads of the federal enforcement agencies during this period. When officials served for only a short time, usually as acting heads of the

\section{See, e.g., Timothy J. Muris, The FTC and the Law of Monopolization, 67} ANTITRUST L.J. 693 (2000).

37 The government prevailed on some issues and lost on others in United States v. Microsoft Corp., 253 U.S. F.3d 34 (D.C. Cir.), cert. denied, 534 U.S. 952 (2001). The court rejected the government's claims in United States v. AMR Corp., 335 F.3d $1109\left(10^{\text {th }}\right.$ Cir. 2003); United States v. Dentsply Int'l, 2003 U.S. Dist. LEXIS 14139 (D. Del. Aug. 8, 2003).

38 The Commission's recent dominant firm matters are recounted in Federal Trade Commission, 2003 Year in Review, at 3-5. 
FTC or the Antitrust Division, their tenure is combined with that of the nearest official who server a longer time. Tables 5 through 7 rank agency heads by average number of cases brought per year of their tenure. Table 5 provides this data for civil horizontal restraint cases, Table 6 covers vertical restraint cases, and Table 7 counts dominant firm cases. Table 8 lists agency heads chronologically and then provides the ordinal rankings for specific types of cases from Tables 5 through 7.

Table 5: Civil Horizontal Restraint Cases $^{39}$ Average Cases per Year by Tenure of Agency Head

\begin{tabular}{|c|c|c|}
\hline Muris & 2001- 2004 (FTC) & 9.8 \\
\hline Steiger & 1989-1995 (FTC) & 8.1 \\
\hline Miller & 1981-1985 (FTC) & 8.0 \\
\hline Bingaman & 1993-1996 (DOJ) & 7.0 \\
\hline Calvani/Oliver $^{40}$ & 1985-1989 (FTC) & 6.9 \\
\hline Pitofsky & 1995-2001 (FTC) & 6.3 \\
\hline Baxter/McGrath & 1981-1985 (DOJ) & 4.3 \\
\hline Rill (James/Bidley/Clark) ${ }^{41}$ & 1989-1993 (DOJ) & 2.5 \\
\hline James/Pate & 2001-2004 (DOJ) & 1.9 \\
\hline Klein (Melamed) ${ }^{42}$ & 1996-2001 (DOJ) & 1.3 \\
\hline
\end{tabular}

39 This table omits DOJ civil horizontal restraint cases that seek to recover civil damages for U.S. government agencies injured by cartels that DOJ previously has challenged in a criminal proceeding.

$40 \quad$ Terry Calvani was acting FTC Chairman from October 1985 until April 1986.

41 Rill's tenure includes 13 months in which Charles James, Mark Gidley, and John Clark served as Acting Assistant Attorneys General. James/Gidley/Clark brought 4 of the10 cases in the Rill totals.

$42 \quad$ Klein's tenure includes 9 months in which Douglas Melamed served as Acting Assistant Attorney General. Melamed brought no civil horizontal restraints cases. 


\begin{tabular}{|c|c|c|}
\hline Ginsburg/Rule ${ }^{43}$ & 1985-1989 (DOJ) & 0.3 \\
\hline
\end{tabular}

Table 5 suggests that the most significant difference is not between agency heads under Republican administrations versus agency heads under Democratic administrations but between the FTC and the DOJ. The three most active heads were FTC chairpeople and the three least active headed the Antitrust Division. Given that most of the DOJ's horizontal nonmerger enforcement is criminal, this result is not surprising.

\section{Table 6: Vertical Restraint Cases}

Average Cases per Year by Tenure of Agency Head

\begin{tabular}{|c|c|c|}
\hline Bingaman & 1993-1996 (DOJ) & 2.1 \\
\hline Pitofsky & 1995-2001 (FTC) & 1.1 \\
\hline Steiger & 1989-1995 (FTC) & 0.9 \\
\hline Miller & 1981-1985 (FTC) & 0.5 \\
\hline Rill (James/Bidley/Clark) ${ }^{44}$ & 1989-1993 (DOJ) & 0.3 \\
\hline Baxter/McGrath & 1981-1985 (DOJ) & 0 \\
\hline Ginsburg/Rule & 1985-1989 (DOJ) & 0 \\
\hline Calvani/Oliver & 1985-1989 (FTC) & 0 \\
\hline Klein(Melamed) ${ }^{45}$ & 1996-2001 (DOJ) & 0 \\
\hline Muris & 2001-2004 (FTC) & 0 \\
\hline
\end{tabular}

43 The Rule, Klein, and Pate tenures in tables 5 through 8 include periods in which Rule, Klein, and Pate served as Acting Assistant Attorneys General before their appointments as Assistant Attorneys General.

44 Rill's tenure includes 13 months in which Charles James, Mark Gidley, and John Clark served as Acting Assistant Attorneys General. John Clark brought the one case (the Canstar Sports RPM matter) in the Rill totals.

$45 \quad$ Klein's tenure includes 9 months in which Douglas Melamed served as Acting Assistant Attorney General. 


\begin{tabular}{|l|l|l|}
\hline James/Pate & 2001-2004 (DOJ) & 0 \\
\hline
\end{tabular}

Because so few vertical cases were brought the variations between agencies in Table 6 is less pronounced than it was for horizontal restraints in Table 5. Again, there is no clear pattern between Democrats and Republicans. While Janet Steiger, a Republican, and Robert Pitofsky, a Democrat, were two of the most aggressive enforcers in this category, their counterparts, James Rill and Joel Klein, did not bring vertical cases. Unlike horizontal restraints, there is also no clear difference between the FTC and DOJ. Indeed, the most (Ann Bingaman) and least (Joel Klein) aggressive enforcers were both at the Antitrust Division and both Clinton appointees.

Table 7: Dominant Firm Cases (Attempted Monopolization and Monopolization) Average Cases per Year by Tenure of Agency Head

\begin{tabular}{|l|l|l|}
\hline Muris & 2001-2004 (FTC) & 1.5 \\
\hline Bingaman & $1993-1996$ (DOJ) & 1.2 \\
\hline Pitofsky & $1995-2001$ (FTC) & 0.7 \\
\hline Klein (Melamed) & $1996-2001$ (DOJ) & 0.6 \\
\hline Miller & $1981-1985$ (FTC) & 0.5 \\
\hline Baxter/McGrath & $1981-1985$ (DOJ) & 0.3 \\
\hline Ginsburg/Rule & $1985-1989$ (DOJ) & 0 \\
\hline Calvani/Oliver & $1985-1989$ (FTC) & 0 \\
\hline Rill (James/Bidley/Clark) & $1989-1993$ (DOJ) & 0 \\
\hline Steiger & $1989-1995$ (FTC) & 0 \\
\hline James/Pate & $2001-2004$ (DOJ) & 0 \\
\hline
\end{tabular}

Like vertical cases, the dominant firm numbers in Table 7 are quite small. The main difference is chronological, not political or even agency-specific: clearly the antitrust agencies brought more of these cases recently.

Table 8: Summary of Horizontal Restraint, Vertical Restraint, and Dominant Firm Cases 
(listed chronologically and showing rank in number of types of cases)

$\begin{array}{llll}\text { Average Cases per Year by Tenure of Agency Head } & \text { HR } & \text { VR } & \text { DF }\end{array}$

\begin{tabular}{|c|c|c|c|c|}
\hline Baxter/McGrath & 1981-1985 (DOJ) & 7 th & tied last & $6^{\text {th }}$ \\
\hline Miller & 1981-1985 (FTC) & $3 \mathrm{rd}$ & 4 th & 5 th \\
\hline Ginsburg/Rule & $1985-1989(\mathrm{DOJ})$ & last & tied last & tied last \\
\hline Calvani/Oliver & 1985-1989 (FTC) & 5 th & tied last & tied last \\
\hline Rill (James/Bidley/Clark) & 1989-1993 (DOJ) & 8 th & $5^{\text {th }}$ & tied last \\
\hline Steiger & 1989-1995 (FTC) & 2nd & $3 \mathrm{rd}$ & tied last \\
\hline Bingaman & 1993-1996 (DOJ) & 4 th & $1 \mathrm{st}$ & 2 nd \\
\hline Klein (Melamed) & 1996-2001 (DOJ) & 10th & tied last & 4 th \\
\hline Pitofsky & 1995-2001 (FTC) & 6th & 2nd & $3 \mathrm{rd}$ \\
\hline James/Pate & 2001-2004 (DOJ) & 9th & tied last & tied last \\
\hline Muris & 2001-2004 (FTC) & $1 \mathrm{st}$ & tied last & $1 \mathrm{st}$ \\
\hline
\end{tabular}

Table 8 presents all three categories, with the numerical rank from first to last in each category of case. No one agency head was the most aggressive, by case count, in all three categories. Nor does the Table reveal that the Clinton Administration was obviously more aggressive than its GOP predecessors. At the bottom, however, the second-term Reagan Antitrust Division, headed by Douglas Ginsburg and Charles Rule, was the least aggressive in each category. Indeed, the charge that the Reagan Administration had no civil, nonmerger enforcement program was true for DOJ in those years. The charge is demonstrably false however for the remaining three fourths of the Reagan appointees who each had numerous civil cases against horizontal restraints. Moreover, as discussed above, Baxter and Miller prosecuted important dominant firm matters.

\section{(b.) Merger Enforcement}

As with non-horizontal, nonmerger enforcement, the Reagan administration contracted 
merger enforcement policy. Before 1980, there was a period of expansive federal enforcement activity - highly aggressive in the early to mid-1960s, with a noteworthy but modest effort, via the 1968 DOJ guidelines, by Don Turner to prevent further extensions. The 1970s, owing to General Dynamics (1974) and various lower court decisions, did not feature further efforts to broaden the reach of merger prohibitions. Nonetheless, the agencies neglected to retreat materially from flawed analytical approaches. This is evident in the FTC's faltering record in federal court merger challenges in cases filed in the years preceding the Reagan Administration. The indifference or hostility to modern economic developments contributed to the Commission's increasing difficulty in federal court litigation involving mergers. Between 1977 and 1983, in federal court merger cases the FTC won only 8 of 22 cases. ${ }^{46}$

The 1980s set a norm that has been sustained, in large part, through the 1990s. Bill Baxter's 1982 guidelines have become the established norm for evaluating mergers, widely accepted not only in the United States, but around the world. ${ }^{47}$ To be sure, the cumulative experience under the Guidelines has stimulated an evolution in enforcement patterns and some changes in the Guidelines. If one learns from experience, such an evolution should be expected and reflects neither ideological nor personnel shifts.

Table 9: Merger Challenges as a Percentage of Hart-Scott-Rodino Filings By Tenure of Agency Head

$46 \quad$ See Carol T. Crawford et al., Federal Trade Commission Law Enforcement in the 1980s: A Progress Report on the First Three Years of the Reagan Administration Leadership October 1981 to October 198441 (Oct. 1984) (report available from the FTC Library). The cases for which final judicial decisions were issued had commenced before 1981.

$47 \quad$ See Thomas B. Leary, The Essential Stability of Merger Policy in the United States, 70 ANTITRUST L.J. 105 (2002). 


\begin{tabular}{|l|l|l|}
\hline Steiger & $1990-1995$ (FTC) & $1.51 \%$ \\
\hline Klein (Melamed) & $1997-2000$ (DOJ) & $1.03 \%$ \\
\hline Miller & $1982-1985$ (FTC) & $.96 \%$ \\
\hline Bingaman & $1994-1996$ (DOJ) & $.92 \%$ \\
\hline Baxter/McGrath & $1982-1985$ (DOJ) & $.84 \%$ \\
\hline Rill, et al. & $1990-1993$ (DOJ) & $.75 \%$ \\
\hline Pitofsky & $1996-2000$ (FTC) & $.75 \%$ \\
\hline Calvani / Oliver & $1986-1989$ (FTC) & $.70 \%$ \\
\hline Ginsburg / Rule & $1986-1989$ (DOJ) & $.39 \%$ \\
\hline
\end{tabular}

Table 9 repeats the categorizations of Tables 5 through 8 , this time for mergers, but

without the current enforcers. The statistic is the number of mergers challenged as a percentage of Hart-Scott-Rodino filings. ${ }^{48}$ Because the filing threshold changed in March 2001, comparable data is no longer collected. Although this is an admittedly crude statistic, three features of merger enforcement patterns stand out. First, a close look at the data bears out the conclusion about the essential stability of post-1981 U.S. merger policy. Within this general pattern there is only one noteworthy peak (during Janet Steiger's FTC chairmanship) and one major valley (the tenures of Douglas Ginsburg and Charles Rule as Assistant Attorney General for Antitrust). There are also some difference in the volume of enforcement events attributable to adjustments

48 Challenge data is drawn from: (i) FTC Mission Accomplishments for the fiscal years 1986 through 2000 and counts as challenges the sum of preliminary injunctions authorized, administrative complaints issued, FTC Part II consents accepted, and transactions withdrawn after issuance of a second request (in all cases, duplicate cases were eliminated); (ii) DOJ Workload Statistics for the years 1988 through 2000, counting as challenges the sum of merger actions filed in the district court and transactions abandoned or restructured prior to filing a complaint as a result of an announced challenge; and (iii) HSR Annual Reports filed for the calendar years 1982-1985 and for the fiscal years 1986 and 1987 (one report), which in the text and footnotes describe cases brought and transactions abandoned. Duplicate cases were eliminated. In all cases, data was collected as of the date the challenge began. 
in regulatory policy that significantly altered the type of transactions that the antitrust agencies

reviewed. ${ }^{49}$ Because by law, only one agency can review a proposed merger, the agencies divide merger enforcement between them.

The Goldilocks story incorrectly treats all federal merger enforcement during the Reagan administration as homogeneous. This is perhaps a consequence of the unfortunate tendency of DOJ and FTC leadership during Ronald Reagan's second term to emphasize the types of cases they would not bring and to mute their positive enforcement intentions. ${ }^{50}$ As with nonmerger enforcement, however, this view of homogeneity is incorrect. The DOJ in President Reagan's second term was a decided outlier, but the other three Reagan periods are consistent with their successors. The pendulum narrative also fails to note that enforcement under an FTC chairman appointed during Bush I far exceeded that under President Clinton's appointees.

A second, related point is that merger policy from 1981 through the 1990 s evolved to gradually give business managers greater freedom to complete mergers. The merger guidelines have evolved since 1982, with amendments adopted in 1984, 1992, and 1997. At least part of that evolution directly contradicts those who would argue that antitrust enforcement toughened in the 1990s. During the first few years under the 1982 guidelines, the numerical thresholds were given more credence. For example, in 1984, the Reagan FTC successfully challenged a merger

49 The communications sector provides several examples. DOJ reviewed a significant number of radio mergers in the 1990s and demanded remedies in some of these transactions. The increase in radio mergers stemmed from a loosening of regulatory controls governing the number of stations a single firm could own in a particular service area. During the same decade, changes in statutes and implementing regulations likewise increased the ability of telecommunications service providers to merge their operations.

$50 \quad$ See Report of the ABA Antitrust Law Section Task Force on the Antitrust Division of the Department of Justice, reprinted in 58 ANTITRUST L.J. 735, 745 (1990) (urging DOJ to "articulate and garner public support for a positive enforcement agenda" and recommending that 
involving music distribution that would have reduced the number of significant competitors from 6 to $5 .^{51}$ When a 6 to 5 merger involving the same sector took place in the Clinton administration, the transaction cleared the FTC without a detailed investigation. ${ }^{52}$ Moreover, the Reagan administration's analysis of gasoline distribution, carried out less than two years after the issuance of the1982 guidelines, applied a tighter numerical threshold than that of the 1990s. In mergers such as Chevron/Gulf, there were many wholesale overlaps, with a range of post-merger Herfindahls from highly concentrated to unconcentrated. Rather than perform a separate, detailed investigation in each geographic market, ${ }^{53}$ the Commission applied a rule of thumb for requiring divestitures. Presumptively, divestitures were sought when the Herfindahls exceeded 1000 - the beginning of the guidelines' mid-range of concentration - and the delta exceeded 100. Since that time, the agencies have not obtained relief in markets with such a low HHI.

Fealty to the guideline numerical levels was abandoned as the agencies gained experience. Particularly in 1992, the guidelines were amended to codify the existing practice of giving more weight to qualitative factors. The 1982 and 1984 guidelines had given more emphasis to quantitative thresholds, particularly involving concentration levels above the 1800 HHI boundary. ${ }^{54}$ The 1992 guidelines reduced the significance of the 1800 threshold by inviting the Division end "non-enforcement rhetoric"). 1998 , at D2.

53 The merging parties were anxious to close the transaction and did not desire such investigations.

54 The 1982 guidelines denominated markets with a post-merger HHI of 1800 or more as "highly concentrated." The significance of the HHI thresholds employed in the 1982 guidelines thresholds is examined in ABA Antitrust Section, Monograph No. 12, Horizontal 
fuller consideration of other conditions that helped predict whether price increases were likely in the post merger period. ${ }^{55}$

A third observation concerns the tendency to criticize Reagan-era merger policy on the ground that lax enforcement helped spur the merger wave of the 1980s. ${ }^{56}$ If Reagan antitrust policy contributed to the merger wave of the 1980s, what is one to conclude about antitrust policy in the 1990s - a decade in which a still larger merger wave transpired? Antitrust policy has virtually nothing to do with the overall level of merger activity in the economy, a completely

Mergers: Law and Policy 196-97 (1986).

55 Compare the language of the 1982 and 1984 Merger Guidelines to the language of the 1992 Horizontal Merger Guidelines. In 1982, the guidelines stated that, for mergers that would result in a post merger HHI above 1800, the Department of Justice was "likely to challenge mergers ... that produce an increase in the HHI of 100 points or more." United States Dep't of Justice, Merger Guidelines (June 14, 1982), reprinted int Trade Reg. Rep (CCH) If 13,102 at § 3.A.1. In 1984, the Department of Justice made it clear that, even at the 1800/100 level, other factors, such as ease of entry, the financial condition of firms, and changing market conditions, would be considered in determining whether an enforcement action was warranted. However, only in "extraordinary cases w[ould] such factors establish that the merger is not likely to substantially less competition." United States Dep't of Justice, Merger Guidelines (June 14, 1984), reprinted in 4 Trade Reg. Rep. (CCH) If 13,103 at § 3.11 .

The 1992 Horizontal Merger Guidelines went much further to limit the importance of concentration statistics, indicating only that there was "a presumption" that mergers at the 1800/100 level "are likely to create or enhance market power or facilitate its exercise". "[T]he presumption [could] be overcome" by a showing that other factors, such as entry, make it unlikely that the merger will have an anticompetitive effect." United States Dep't of Justice and Federal Trade Commission, Horizontal Merger Guidelines (Apr. 2, 1992), reprinted in 4 Trade Reg. Rep. (CCH) I[ 13,104 at $\S 1.51$.

56 Commentaries that identify lax merger enforcement as a stimulus for the merger wave of the 1980s include Milton Handler, Is Antitrust's Centennial a Time for Obsequies or for Renewed Faith in Its National Policy?, 10 CARDOZO L. REV. 1933, 1940 (1989) ("Hardly a day passes without news accounts of massive mergers or takeovers of dubious legality which go unchallenged and which produce a chain reaction in stimulating waves of new acquisitions."); Robert Pitofsky, Does Antitrust Have a Future?, 76 GEO. L.J. 321, 326 (1987) (“A more vigorous, pragmatic antitrust enforcement policy should be restored. The most pressing area is merger nonenforcement - far more permissive these days than the Administration's own guidelines - where failures to act and loose rhetoric have contributed to a foolish and wasteful surge of giant consolidations."). 
unsurprising fact given that only a few mergers present significant antitrust concerns. The mergers of the 1990s were not somehow more benign or procompetitive than the mergers of the 1980s. What occurred in both decades was a process of restructuring that permitted U.S. firms to adjust to fundamental changes in the economy at home and abroad. Antitrust policy throughout this period gave most merging firms the ability to realize efficiencies while opposing transactions that threatened to create or reinforce market power.

\section{Limitations of the Pendulum Narrative}

Beyond its failure to find support in case counts, the pendulum narrative suffers from three particularly serious limitations. The first is that it attributes policy adjustments over time mainly to political affiliation and to the idiosyncratic preferences of individual enforcement officials ("ideology"). This approach ignores important institutional factors that lead competition authorities to change direction. Second, the pendulum narrative pays little attention to activities other than the prosecution of cases - and usually "big" cases, at that. Non-litigation activities that have a major impact on public policy, such as the FTC's Generic Drug study, ${ }^{57}$ are

overlooked. Less-obviously significant cases, such as Indiana Federation of Dentists ${ }^{58}$ and Ticor Title Insurance, ${ }^{59}$ that alter doctrine are deemed irrelevant.

Third, the narrative derives its power by accentuating swings across different periods. This inspires an exaggeration of differences across periods by obliterating facts that do not fit

57 See Federal Trade Commission, Generic Drug Entry Prior to Patent Expiration: An FTC Study (July 2002), available at <http://www.ftc.gov/os/2002/07/genericdrugstudy.pdf . This study led the FDA to change its rules and the Congress to enact new legislation. the Rule of Reason).

FTC v. Indiana Fed'n of Dentists, 476 U.S. 447 (1986) (clarifying application of 
neatly the story of polar extremes. It also causes narrators to treat each administration as unrelated to periods before and after. In baseball terms, individual administrations do not always pitch "complete games" in prosecuting cases or pursuing other initiatives. Matters begun in one administration often spill over into another. The contributions of two or more administrations frequently determine the outcome of the entire initiative. If baseball kept track of pitching statistics in a manner comparable to the pendulum narrative, it would count the total number of starts without counting saves.

\section{Understanding the Development of Modern Federal Enforcement Policy}

A fundamental reason to review past experience is to improve our understanding about how to formulate sensible competition policies. This section identifies a number of lessons from our experience over the past four decades.

\section{A. The Need for Continuous Reassessment}

There is a temptation to attribute policy choices that we know ex post to be misguided to the irrationality of individual decision makers or institutions. To say that organizations or agency officials are irrational can be appealing, but it hardly explains the problem of bad policy choices. The more interesting issue is why smart people sometimes make bad choices. The challenge is to identify avoidable errors and to suggest how to avoid future missteps.

One avoidable error for an antitrust agency is to pay too little attention to developments in economic learning and industry conditions that undermine existing or contemplated enforcement programs. This section will use three examples from the 1970s: the experience with dominant firm misconduct/shared monopoly, vertical restraints, and merger efficiencies. In each case, there are failures to take account of new developments that cast doubt upon the wisdom of

State Action Doctrine). 
investing substantial resources for enforcement in these areas.

\section{Dominant Firm Misconduct}

From the late 1960s until Ronald Reagan's election in 1980, the DOJ and the FTC maintained an ambitious agenda of monopolization and attempted monopolization initiatives that proposed structural remedies to erode the market positions of dominant firms in a wide swath of the American economy. This enforcement stemmed from considerably more than brute populism. Many measures later criticized as simple-minded assaults upon corporate size employed what their sponsors viewed to be mainstream economic thinking. ${ }^{60}$

The deconcentration impetus of the period rested upon economic literature that found a strong positive relationship between concentration and profitability, and suggested that enforcement policy be based on simple market concentration numbers. ${ }^{61}$ Industries with high concentration ratios were presumed to perform poorly, particularly if accounting profits were high. The doctrine gave little weight to the possibility that lower costs might explain any

$60 \quad$ See William E. Kovacic, Failed Expectations: The Troubled Past and Uncertain Future of the Sherman Act as a Tool for Deconcentration, 74 IOWA L. REV. 1105, 1136-41 (1989) (discussing intellectual foundations for antitrust deconcentration initiatives pursued in the late 1960 s and in the 1970s).

$61 \quad$ One highly influential scholarly work in this period was Carl Kaysen's and Donald Turner's Antitrust Policy: An Economic and Legal Analysis, which appeared in 1959. Kaysen and Turner wrote that "The principal defect of present antitrust law is its inability to cope with market power created by jointly acting oligopolists." Id. at 110 . They urged Congress to adopt new legislation compelling the deconcentration of various sectors of the economy. Id. at 110-19, 261-66. In 1969, a blue ribbon presidential task force headed by Dean Phil Neal of the University of Chicago recommended deconcentration variants of the Kaysen and Turner proposals. See White House Task Force Report on Antitrust Policy, reprinted in A NTITRUST L. \& ECON. REV. 11, 14-15, 65-76 (1968-69). Task force members who endorsed the deconcentration measure included such prominent academics as Dean Neal, William Baxter, William K. Jones, Paul MacAvoy, James McKie, Lee Preston, and James Rahl. 
superior profitability of large firms. ${ }^{62}$

A striking number of the FTC's most important antitrust cases in the 1970s reflected the teaching of this simple market concentration doctrine. ${ }^{63}$ Early in the decade, the FTC ranked industries with a model developed primarily to attack concentrated industries. The agency undertook numerous industry-wide cases, including the breakfast cereals case, petroleum industry litigation, and a massive investigation of the automobile industry. In the cereals case, for example, the Commission alleged a shared monopoly in the ready-to-eat breakfast cereals industry and argued that heavy advertising, product and package-size proliferation, and shelf allocation plans were the principal barriers to entry. ${ }^{64}$

The analytical foundations for the agencies' cases rested upon theories of coordination and exclusion that failed to grapple with then-recent developments in industrial organization economics. It would be an unfair simplification to say the agencies merely followed a simpleminded belief that large firms were a menace -- although that was the policy import of the model, the model was more sophisticated and had several respected adherents in the competition policy community. The problem was that the model on which the agencies relied decisively was

62 It also drew heavily from studies indicating that a deconcentration program was unlikely to sacrifice significant scale economies or other efficiencies. Kovacic, Failed Expectations, supra note 60, at 1136, (citing Leonard Weiss, The Concentration - Profits Relationship and Antitrust, in INDUSTRIAL CONCENTRATION: THE NEW LEARNING 184-272 (1974)). See also F. Scherer et Al., The Economics of Multi-Plant Operations: An InTERNATIONAL COMPARISONS STUdy (1975); Roger Sherman \& Robert Tollison, Public Policy Toward Oligopoly: Dissolution and Scale Economies, 4 ANTITRUST L. \& ECON. REV. 77, 78 (Summer 1971).

63 See, e.g., Wesley Liebeler, Bureau of Competition: Antitrust Enforcement Activities, in The FEDERAL Trade COMMISSION SINCE 1970: ECONOMIC REGULATION AND BurEAUCRATIC BEHAVIOR 65-73 (Kenneth W. Clarkson \& Timothy J. Muris, eds. 1981).

$64 \quad I d$. 
crumbling. The more accurate and sobering characterization of the FTC's mistake in pursuing this initiative, which consumed vast agency resources, was that the Commission launched and expanded it in the face of growing evidence that the program's analytical basis was losing intellectual support.

The shared monopoly and other theories used in the 1970s to attack concentration became discredited. The FTC's motivation to reassess the validity of these enforcement approaches did not come from independent, internal reassessment. Instead, the imperative to change came from developments taking place within the federal courts in the mid- to late-1970s. The decision of the court of appeals in Berkey Photo ${ }^{65}$ punctuated the judiciary's attitude about antitrust policy toward dominant firms. In the course of exonerating Eastman Kodak of liability for monopolization, the Second Circuit stated:

A large firm does not violate $\S 2$ simply by reaping the competitive rewards attributable to its efficient size, nor does an integrated business offend the Sherman Act whenever one of its departments benefits from association with a division possessing a monopoly in its own market. So long as we allow a firm to compete in several fields, we must expect it to seek the competitive advantages of its broad-based activity - more efficient production, greater ability to develop complementary products, reduced transaction costs, and so forth. ${ }^{66}$

The caution expressed in Berkey and other judicial decisions was reinforced by economic research indicating that deconcentration might actually raise prices and lower quality because many firms gained larger market share through lower costs or higher quality, rather than through

65 Berkey Photo, Inc. v. Eastman Kodak Co., 603 F.2d 263, 276 (2d Cir. 1979).

66 Berkey Photo, Inc. v. Eastman Kodak Co., 603 F.2d 263, 276 (2d Cir. 1979), cert. denied, 444 U.S. 1093 (1980). 
practices that harmed consumers. A harbinger of the distintegration of the intellectual basis for deconcentration of the economy was the 1974 Airlie House conference on "the new learning" about industrial concentration. Structured as a debate about deconcentration policy, this conference supplied a forum for opponents to synthesize and highlight the literature that challenged the underlying economic assumptions of deconcentration policies. ${ }^{67}$ Among the most important themes was that, contrary to the conventional view of bigness, superior performance not only could, but typically did, account for large firms achieving and maintaining large market shares over time. ${ }^{68}$ The Airlie House conference and subsequent academic attacks on the structural model and its policy proposals severely weakened the intellectual support for deconcentration. $^{69}$

Despite the growing evidence of the flaws in the deconcentration program, the agencies not only continued their misguided efforts, they expanded them. Two initiatives are especially noteworthy. The first was the FTC's automobile investigation. Formally begun in the Summer of 1976, the effort was built upon the agency staff's endorsement of the horizontal and vertical dismemberment of the industry leader (General Motors) and its belief that the second and third members of the American "Big Three" (Chrysler and Ford) could be worthy candidates for divestiture as well.

The auto industry investigation collapsed of its own weight and marketplace realities in

67 See Kovacic, Failed Expectations, supra note 60, at 1138. The proceedings of the conference were published in INDUSTRIAL CONCENTRATION: THE NEW LEARNING (1974).

68 See, e.g., ROBERT Bork, The ANTITRUST PARAdOX 163-97 (1978).

69 See, e.g., Paul Pautler, A Review of the Economic Basis for a Broad-Based Horizontal Merger Policy, 28 ANTITRUST BULL. 571 (1983) (reviewing relevant literature). 
May $1981 .^{70}$ One can take some satisfaction from the Commission's eventual recognition that the inquiry's premises were faulty and the investigation should end. Nonetheless, it is sobering that the FTC did not perceive fundamental flaws in the undertaking when it began in 1976.

Contemporary economic learning had raised grave doubts about the simple market concentration doctrine. Moreover, the rapidly changing market environment should have aroused suspicion about the staff's assessment of competition in the automobile sector. ${ }^{71}$

The second example of the antitrust agencies' failure to follow the developments in the law, the academy, and the marketplace is even more surprising and less defensible. Despite the cautions from the new learning about deconcentration, proposals to restructure dominant firms using no-fault theories of liability received considerable attention in the late 1970s. In 1979 President Carter's National Commission for the Review of Antitrust Laws and Procedures (NCRALP) recommended amendment of the Sherman Act to redress monopoly power not

70 For a discussion of the background and conclusion of the FTC's automobile investigation, see Timothy J. Muris, Chairman, Federal Trade Commission, Improving the Economic Foundations of Competition Policy, Remarks at the George Mason University Law Review's Winter Antitrust Symposium, Washington, D.C. (Jan. 15, 2003), available at, <http://www.ftc.gov/speeches/muris/improveconfoundatio.htm>.

71 At least three specific developments concerning the auto industry undermined the FTC's staff approach. The first was John McGee's 1973 article, Economies of Size in Auto Body Manufacture, 16 J.L. \& ECON. 239 (1973), which persuasively argued that much of GM's success derived from its ability to spread the enormous costs of setting up dies to stamp out auto body parts across a much larger volume than its competitors. A second real world phenomenon that undermined the rationale for the auto industry inquiry was growing foreign competition. Surprisingly, the FTC proponents of restructuring the U.S. producers dismissed foreign suppliers as likely to have little competitive impact. A third phenomenon that undercut the case for conducting an investigation was uncertainty over gasoline prices. The crude oil price shock of 1973-74 had increased gasoline prices dramatically and had given an enormous boost to sales of fuel efficient vehicles. This spurred imports, particularly from Japan. 
attributable to continuing superior performance. ${ }^{72}$ Before NCRALP and in other forums, leading FTC officials endorsed the no-fault concept. ${ }^{73}$ Contemporaneous news accounts indicate that the Commission staff was investigating possible candidates for a Section 5 proceeding that would apply a no-fault liability standard. ${ }^{74}$ The agencies' stubborn adherence to discredited deconcentration theories in the late 1970s is one of the worst mistakes in antitrust's long history.

\section{Distribution Restraints}

In the 1960s federal antitrust policy displayed acute skepticism toward vertical distribution restraints. ${ }^{75}$ Two cases underscore the attitude of the federal enforcers. In Federal Trade Commission v. Brown Shoe Co., ${ }^{76}$ the FTC successfully used Section 5 of the FTC Act to attack an exclusive dealing arrangement that resulted in a vertical foreclosure of less than one

121 Report to the President and the Attorney General of the National Commission for the Review of Antitrust Laws and Procedures viii-ix (1979) [hereinafter NCRALP Report].

73 See id. at 152 \& n. 34 (reporting that FTC submitted statement endorsing no-fault monopolization concept and recommending passage of legislation to permit no-fault causes of action); Robert Pitofsky, Commissioner, Federal Trade Commission, In Defense of 'No Fault Monopoly' Proposals, Presentation Before the $20^{\text {th }}$ Annual Law Symposium of the Columbia University Law School (Mar. 31, 1979) (defending no-fault monopolization concept).

$74 \quad$ See James W. Singer, Should the FTC Break Up Monopolies Even If They Have Done Nothing Wrong?, NAT'L L. J., Sept. 27, 1980, at 1609 (discussing FTC inquiry into possible no-fault monopolization claims against Campbell Soup, Eastman Kodak, Gerber, and Proctor \& Gamble).

75 In a representative statement of this attitude in 1966, as Assistant Attorney General for Antitrust, Donald Turner remarked that he approached vertical "territorial and customer restrictions not hospitably in the common law tradition, but inhospitably in the tradition of antitrust law." Donald F. Turner, Some Reflections on Antitrust, in 1966 N.Y. STATE BAR ASSOCIATION ANTITRUST LAW SYMPOSIUM 1, 1-2 (1966).

$76 \quad 384$ U.S. 316 (1966). 
percent. ${ }^{77}$ The Commission expressed alarm that "[o]f the approximately 1,000 shoe manufacturers in 1959, the top 70 manufacturers accounted for approximately 54 percent of the shoe production." ${ }^{, 78}$ The five largest producers, the Commission added, produced 24 percent of shoes made in $1959 .{ }^{79}$ Responding to Brown Shoe's argument that its exclusive dealing contracts improved the performance of the firm's production and marketing operations, the Commission said that efficiency considerations were irrelevant to evaluate the legality of the arrangements. ${ }^{80}$

The Justice Department in the 1960s was no less enthusiastic about attacking such restrictions. It was the Antitrust Division's case, United States v. Arnold, Schwinn \& Co. ${ }^{81}$ that

77 The distribution program at issue in Brown Shoe affected 766 of the 70,000 U.S. stores classified as retail shoe outlets. Brown Shoe Co., 62 F.T.C. 697, 711-12 (1963). The economic conditions of the shoe industry at the time of the case are examined in detail in John Peterman, The Federal Trade Commission v. Brown Shoe Company, 18 J.L. \& Econ. 361 (1975).

78 Brown Shoe, 62 F.T.C. at 717-18.

$79 \quad$ Id.

80 The Commission observed:

We need not concern ourselves here with the arguments of respondent and counsel supporting the complaint about the intrinsic economic merits of line concentration against the advantages of selecting only the best items from several lines in the same price and style ranges....

The economic justification, if any, of line concentration is irrelevant to the issues presented to us here. While line concentration itself may or may not be economically justifiable, there is no economic justification for making the adherence to this doctrine the subject of agreement between buyer and seller and enforcing the agreement to the latter's advantage.

Id. at 709 .

81388 U.S. 365 (1967). 
provided the vehicle for the Supreme Court's ruling in 1967 that all nonprice vertical restraints were illegal per se. ${ }^{82}$ The policies of the two enforcement agencies gradually diverged in the years before Continental T.V., Inc. v. GTE Sylvania Inc., ${ }^{83}$ which reversed Schwinn in 1977 and held that the rule of reason governed all nonprice vertical restraints. In the early 1970s, the Justice Department prosecuted a substantial number of vertical restraints cases, including challenges to tying, reciprocal dealing, exclusive dealing, and resale price maintenance (RPM). By the mid-1970s, however, attention to new economic literature on the economic consequences of vertical restraints, much of it focusing on the role of vertical restraints in reducing transaction costs, appears to have led the Antitrust Division to use its discretion not to challenge nonprice arrangements. ${ }^{84}$ Vertical restraints became a diminishing focal point of DOJ's enforcement program, although the Antitrust Division did take the jarring step in 1980 of initiating a criminal

82 Id. at $376-82$.

83433 U.S. 36 (1977).

84 Thomas Kauper, who headed the Antitrust Division from 1974 to 1976, has described DOJ's thinking at the time:

[I]n the years I served as Assistant Attorney General, vertical territorial restrictions were per se illegal, according to the Supreme Court's decision in United States v. Arnold, Schwinn \& Co. The rule made no economic sense. We brought no such cases, explaining that the conduct was overt, that those allegedly harmed knew that they were "victims" and had all the facts necessary for application of a per se rule at their disposal, that a private remedy was readily available and there was therefore no reason to expend the Division's resources on such cases.

Thomas E. Kauper, The Justice Department and the Antitrust Laws: Law Enforcer or Regulator?, 35 ANTITRUST BULL. 83, 99 (1990). More generally, Kauper's tenure is probably the most important of any Assistant Attorney General for Antitrust during the 1970s. In addition to retrenching the Antitrust Division's vertical restraints program, Kauper filed the $A T \& T$ monopolization case and began the effort, sustained by his successors, to apply vigorously the stiffened Sherman Act criminal sanctions established by Congress in 1974. 
suit against Cuisinarts for minimum RPM. ${ }^{85}$

In contrast to the DOJ's experience, the FTC's vertical restraints program remained vigorous throughout the 1970 s. $^{86}$ The Commission prosecuted numerous vertical matters, with many involving products- such as stereo equipment, hearing aids, ski bindings, and firearms that require the production of some information or demonstrations at the point of sale to aid consumers in making informed purchasing decisions. To avoid free-riding on the information or services provided by the resellers, manufacturers restricted distribution to allow their resellers to reap a return on their efforts. The principal effect of FTC orders in a significant number of these cases was probably to force manufacturers to use less efficient means for providing point of sale information or services.

As noted above, in 1977 the Supreme Court reversed Schwinn in Sylvania, bowing to "the great weight of scholarly opinion critical of [Schwinn]" and requiring plaintiffs to demonstrate the anticompetitive effect of vertical restraints, particularly their effect on interbrand competition. ${ }^{87}$ The FTC, however, refused to abandon its attack on nonprice vertical restraints. In a 1978 decision involving soft drinks, the Commission stubbornly ignored the new learning endorsed in Sylvania the year before. The Commission had brought administrative complaints in 1971 against manufacturers of concentrate for carbonated soft drinks (including Coca-Cola, Pepsi-Cola, and their bottlers) to eliminate the use of exclusive vertical territories in the

85 The matter was resolved with a consent decree. United States v. Cuisinarts, Inc., 1981-1 Trade Cas. (CCH) II 63,979 (D. Conn. 1981).

$86 \quad$ See Liebeler, Antitrust Enforcement Activities, supra note 63, at 74.

87 Continental T.V., Inc. v. GTE Sylvania Inc., 433 U.S. 36, 57-58 (1977). 
industry. ${ }^{88}$ The complaints alleged that the exclusive territories unreasonably restrained trade because they eliminated competition among bottlers, eliminated competition in the sale and distribution of carbonated soft drinks at the wholesale level, deprived retailers and other customers of the right to purchase from the bottler of their choice at competitive prices, and denied consumers the opportunity to obtain carbonated soft drinks in an unrestricted market at competitive prices.

An FTC administrative law judge, reading Schwinn narrowly, upheld the use of exclusive territories under the rule of reason as leading to greater competition in the carbonated soft drink industry. Nonetheless, the Commission reversed and held that the restrictions unreasonably restrained trade. ${ }^{89}$ Despite the intervening Supreme Court decision in Sylvania and compelling evidence that competition in the carbonated soft drink industry in the presence of territorial restraints had rapidly expanded sales, reduced real prices, and developed innovative marketing, packaging, and products, the Commission majority focused on the alleged anticompetitive absence of intrabrand competition. The Commission's attack on the lack of intrabrand competition thus ignored not only Sylvania's decree that interbrand competition was antitrust's main focus, but also the powerful efficiency justifications for exclusive territories and the thenraging Cola Wars. ${ }^{90}$

88 Similar complaints were also issued against Crush International, Beverages International, Dr Pepper Co., Seven-Up Co., Royal Crown Cola Co., National Industries, Inc., and Cott Corporation. On March 13, 1972, similar complaints also were issued against Canada Dry and Norton Simon, Inc.

$89 \quad$ See The Coca-Cola Co., 91 F.T.C. 517 (1978).

90 See Timothy J. Muris ET AL., Strategy, Structure, And Antitrust in the CARBONATED SOFT-DrinK INDUSTRY (1993) (describing FTC soft drink cases and detailing efficiency rationales for challenged restrictions). The unintended result of the FTC's decision 
The Commission's unwillingness to acknowledge a basic shift in commentary and doctrine also was evident in its case against Russell Stover Candies, Inc. ${ }^{91}$ In July 1980, the Commission sought to extend the reach of the per se ban on resale price maintenance first established in Dr. Miles Medical Co. v. John D. Park \& Sons, Co. ${ }^{92}$ Specifically, the Russell Stover case was consciously designed to overturn the rule in United States v. Colgate \& Co. ${ }^{93}$ that declined to find an agreement for Sherman Act purposes when a manufacturer announces in advance the circumstances in which it will not sell and proceeds to terminate distributors who do not comply with its policy. ${ }^{94}$

By a 3-1 vote, the Commission found liability. Although its decision had left the per se rule against RPM in place, the Supreme Court only three years earlier in Sylvania had cautioned against extensions of per se rules and had stated that the establishment of a per se rule must be based on "demonstrable economic effect."95 Vindicating the position of the dissenting commissioner, ${ }^{96}$ the Eighth Circuit subsequently declined the Commission's invitation to

was special federal legislation to protect the exclusive territories of carbonated soft drink bottlers. See Soft Drink Intrabrand Competition Act, 15 U.S.C. § 3501 (1986).

91 Russell Stover Candies, Inc., 100 F.T.C. 1 (1982) (finding liability), enforcement denied, 718 F.2d 256 ( $8^{\text {th }}$ Cir. 1983).

$$
92 \quad 220 \text { U.S. } 373(1911) .
$$

93250 U.S. 300 (1919).

$94 I$ Id. at 307. The initial decision of the administrative law judge in Russell Stover documents that the Commission intended the case as a frontal assault on Colgate. Russell Stover, 100 F.T.C. at 7 (initial decision) (observing that "[c]omplaint counsel have come up with a test case which has as its purpose a direct challenge to the continued viability of Colgate").

95 Continental T.V., Inc. v. GTE Sylvania Inc., 433 U.S. 36, 57-59 (1977).

96 FTC Chairman James C. Miller III dissented from the Commission's finding of liability and repudiation of Colgate. Russell Stover, 100 F.T.C. at 50-53. 
overturn Colgate. ${ }^{97}$ The FTC declined to seek Supreme Court review of the court of appeals decision. The wisdom of this self-restraint, a step that attracted criticism from those who wished to topple Colgate, soon was demonstrated in Monsanto Co. v. Spray-Rite Service Corp. ${ }^{98}$ in which the Supreme Court reaffirmed its commitment to Colgate.

The 1970s presented the FTC with an opportunity to encourage the retreat from distribution restraints enforcement that commentary and judicial decisions, at least since Sylvania in 1977, had recognized as at odds with sound economic analysis. The Commission's distinctive array of institutional capabilities - for example, its research and analysis functions, its extensive complement of industrial organization economists, and its administrative litigation process provided means for fostering a reassessment. To be sure, the Commission did take some steps to perform this role, particularly through the initiation in the late 1970s of ex post evaluations of the effects of some of its vertical cases. ${ }^{99}$ The Commission's litigation program, however, resisted these developments in the literature and the courts. Rather than help lead a reassessment in the 1970s of enforcement policy, the courts forced the Commission to acknowledge the new learning.

\section{Merger Efficiencies}

Before the dramatic shift in antitrust thinking affected policy, efficiencies were ignored or

\footnotetext{
97 Russell Stover Candies, Inc. v. FTC, 718 F.2d $256\left(8^{\text {th }}\right.$ Cir. 1983).

98 465 U.S. 752 (1984).

99 See Federal Trade Commission, Impact Evaluations of Federal Trade Commission Vertical Restraints Cases (Ronald N. Lafferty et al., eds. 1984) (presenting results of FTC ex post evaluations); see also Beltone Elecs. Corp., 100 F.T.C. 68 (1982) (dismissing complaint challenging exclusive dealing arrangement).
} 
treated as an aggravating, rather than a mitigating, factor. ${ }^{100}$ Consolidation was felt to be inherently undesirable in the quest to preserve numerous small businesses. Exacerbating this state of affairs was the difficulty the enforcement agencies and the courts had in recognizing the existence of efficiencies other than economies of scale. An academic work - Economics as an Antitrust Defense: The Welfare Tradeoffs ${ }^{101}$ - that connected Ronald Coase's 1937 article on The Nature of the Firm ${ }^{102}$ to antitrust analysis was a harbinger of change for the importance of efficiencies as a positive factor in merger analysis. Other economists, courts, and eventually antitrust enforcement officials eventually embraced this new learning on efficiencies.

The enforcement pendulum has not swung back against efficiencies. ${ }^{103}$ Neither is this a static development. Instead, understanding about the types and impacts of efficiencies continues to evolve. Historically, what is striking is the extent to which the "efficiency is bad" view or the more indifferent "efficiencies do not count" perspective prevailed at the FTC in merger analysis well into the 1970s. One survey of FTC decisions taken from 1970 to 1977 shows that the administrative law judge or the Commission made arguments that efficiencies created by a merger should count against its legality or that the absence of such efficiency creation should

100 See, e.g., Thomas B. Leary, Commissioner, Federal Trade Commission, Efficiencies and Antitrust: A Story of Ongoing Evolution, Remarks Before the ABA Section of Antitrust Law 2002 Fall Forum (Nov. 8, 2002), available at <http://www.ftc.gov/speeches/leary/efficienciesandantitrust.htm $>$.

101 Oliver E. Williamson, Economics as an Antitrust Defense: The Welfare Tradeoffs, 58 AM. ECON. REV. 18 (1968).

102 R.H. Coase, The Nature of the Firm, 4 ECONOMICA 386 (1937).

103 See Leary, Essential Stability, supra note 4, at 118-19. 
weigh in favor of legality in 8 of the 18 cases litigated to disposition at the Commission level. ${ }^{104}$ None of the 18 cases even considered the possibility that increased efficiency should count in favor of the merger's legality. As was the case with dominant firm and distribution restraints cases, the agency lagged the courts in aligning merger enforcement with the new economicallyoriented literature that called for a realignment of policy.

\section{B. Matching Commitments to Capabilities}

Too often, the effectiveness of federal antitrust policy in any one period is measured by the number and visibility of cases that the government pursued. Special credit is given to matters that capture broad public attention. Contributions from "smaller" cases or from an agency's application of non-litigation policy instruments are largely disregarded. A subsidiary principal is that a failure to generate a significant number of high profile cases indicates ideological rigidity or a paucity of political fortitude.

Experience with modern antitrust policy shows that these critiques ignore the need to evaluate an agency's competition policy commitments in light of its institutional capabilities. In this regard, there are at least two blind spots. First, the cramped view of what activity matters principally litigation - discourages careful consideration of the full range of capabilities an agency might use to address a competition policy problem. A case-centric perspective, with its emphasis on attention-grabbing prosecutions, at least implicitly discourages an agency's efforts to consider how best to apply other tools within its control.

The second failing is to ignore the consequences of prosecutorial commitments that significantly outrun an agency's capability. A given litigation program can create a serious problem either by taking on so many matters that the agency lacks the human capital to execute 
them well or by pursuing cases that enjoy respectable theoretical support but involve implementation issues likely to prove overwhelming in the prosecution of actual matters.

Incumbent enforcement officials also should be evaluated by the actual results achieved. Managers who ignore this issue could make litigation commitments without adequate regard for the longer term consequences for the agency and for public policy. In the midst of activity for which they can claim credit immediately (i.e., bringing cases), managers may underinvest in other initiatives (e.g., advocacy and research) that benefit the agency and the public in the longer term, or they may fail to recognize that the quality of competition policy will improve if the agency conducts fewer cases skillfully rather than prosecuting more cases poorly.

Three issues that emerge from modern enforcement experience illustrate these capability issues. The first deals with the hazards of undertaking litigation that is unduly expansive either because the sheer volume of ambitious matters exceeds the agency's reach or because the theories on which the cases rely place unsupportable demands on the agency's ability to make fine distinctions between acceptable and prohibited behavior. ${ }^{105}$ The second issue involves changes in the competition policy community that press toward expanding antitrust enforcement regardless of institutional capability. The final issue is the danger that a case-centric conception of proper competition policy retards the development and application of other policy tools that should be part of a comprehensive strategy for addressing complex competition questions.

\section{The FTC Antitrust Policy in the 1970s: Many Bridges Too Far}

To consider the pitfalls of overextension, consider the FTC's antitrust agenda of 25 years

105 See William E. Kovacic, Federal Antitrust Enforcement in the Reagan Administration: Two Cheers for the Disappearance of the Large Firm Defendant in Nonmerger Cases, 12 RES. L. \& ECON. 173, 182-92 (1989) (discussing how limits on an antitrust agency's institutional capacity constrain its ability to prosecute cases successfully). 
ago involving dominant firms. Table 10 indicates the monopolization or attempted

monopolization cases the FTC had initiated and was pursuing as of 1979:

Table 10: FTC Dominant Firm Cases and Industry-Wide Inquiries Pending (Nov. 1978)

\section{MatterComplaint Issued}

Kellogg

Exxon

Borden (ReaLemon)

ITT (Bread)

General Foods (Coffee)

Official Airline Guides

Automobiles ${ }^{106}$

Sunkist

DuPont (Titanium Dioxide)
1972

1973

1974

1974

1976

1976

1976 (inquiry begun)

1977

1978

Most of these matters sought structural relief in the form of divestitures or mandatory licensing of trademarks or other intellectual property. ${ }^{107}$ This list, of course, does not capture the full ambition in the FTC's competition program in the 1970s. It omits noteworthy cases not involving dominant firms - such as AMA, Boise Cascade, Ethyl, and the soft drink bottlers cases - that the FTC had initiated and was then pursuing.

As discussed above, there are strong doubts about the conceptual basis for most matters on this list. In addition, there is a separate, important institutional point to be made. Even if one believed in the wisdom of deconcentration and the structuralist approach to competition policy, there is something wrong with this picture. As the FTC added items to its agenda, one wonders how much attention was given to whether it had the institutional capability to bring them to a successful conclusion. If you believe it was sensible to attempt one shared monopoly case

106 Although it is the only nonlitigation matter on the list, the automobile investigation involved an enormous resource commitment.

107

Matters on this list in which the Commission sought divestitures or mandatory 
(Kellogg), was it wise to begin a second bet-your-agency case of the same type (Exxon) and start a massive investigation that contemplated a third (automobiles)? If you thought it was important for the FTC to develop a case to explore predatory pricing doctrine (ITT), was it wise to add two more resource-intensive and analytically demanding cases of the same type (General Foods and ReaLemon)? And what about supplementing the list with two novel cases testing the boundary of exclusionary practices doctrine (OAG and DuPont), and a matter involving important and sensitive competition concerns in the agricultural cooperative field (Sunkist)?

How this chapter of FTC history ended is well known. The outcome of these attacks on "dominance" raised pervasive doubts about the institutional capabilities of the Commission to handle them successfully. As a group, the deconcentration-minded cases were so ambitious and sweeping in their economic aims that the agencies' capabilities were dramatically overtaxed. ${ }^{108}$ In the 1970s, the FTC would have been far better off had it accepted an enforcement norm to choose a smaller number of matters and handle them well. Is it any surprise that, given the discouraging results of the 1970s program and out of concern about the capability of the institution, the Reagan FTC reevaluated its commitment to dominant firm matters?

The Reagan Justice Department's approach to dominant firm cases was quite different. Bill Baxter asked which of the cases he inherited were worth continuing. Making AT\&T the center of attention and committing the resources needed to design and implement an effective remedy were sensible. Asking fundamental questions about the causes of failure of so many mainstays of the dominant firm campaign of the 1970s was responsible. Diagnosing the reasons

licensing of intellectual property include Exxon, Kellogg, ReaLemon, Sunkist, and DuPont.

108 The DOJ's dominant firm program in the late 1960s and in the 1970s was as ambitious. From 1969 to 1974, the DOJ committed itself to restructuring the world's leading computer producer, the country's two leading tire producers, and the world's largest telephone 
for failure and reassessing the capabilities of the federal agencies were appropriate steps before beginning new dominant firm initiatives.

Another perspective on the fit between commitments and capabilities is to review the number of FTC cases in the 1970s that involved what could be called novel or high risk areas of the law. These include the facilitating practices cases (Boise Cascade and Ethyl), shared monopoly (Exxon and Kellogg), duty to deal (OAG), strategic entry deterrence (DuPont), and the attack on Colgate (Russell Stover). In terms of risk and relative novelty, the AMA professions litigation also belongs on the list. Reciting these matters and the dominant firm cases listed above should not suggest that a competition authority should avoid matters that involve high doctrinal or commercial stakes. Rather, it is serves to highlight what happens when the agency adds new cases without concern for its capacity to execute them and when its portfolio of activities becomes particularly rich in initiatives that involve greater degrees of risk owing to their conceptual foundations or commercial complexity.

A further way to test an agency's sensitivity to institutional capability is to examine the outcomes of litigation. The FTC's record in antitrust litigation in the federal courts took a disastrous turn in the late 1970s and early 1980s. Reflecting the "new learning," federal courts overturned an alarming percentage of the FTC's antitrust cases brought before them. Between 1977 and 1983, the Commission won just 13 of 35 substantive antitrust cases in federal court. By contrast, between 1970 and 1976, the Commission won 21 of the 23 antitrust cases heard on appeal. ${ }^{109}$ In a striking number of instances, the courts were extremely critical of the

system.

109 See Carol T. Crawford et al., Federal Trade Commission Law Enforcement in the 1980s: A Progress Report on the First Three Years of the Reagan Administration Leadership October 1981 to October 198441 (Oct. 1984) (report available from the FTC Library). 
Commission's analysis. ${ }^{110}$

The most influential law and economics scholars have realized a fundamental principle concerning the link between economic analysis and competition policy. The insights of economics have their greatest impact on antitrust law and policy when contained in workable rules and analytical techniques for evaluating business conduct. The suitability of an economic hypothesis for shaping antitrust doctrine must include whether the hypothesis lends itself to standards that courts and enforcement agencies can administer effectively. The importance of administrability is evident for those who have played a central role in shaping antitrust doctrine and policy in the past few decades. Many of the strongest contributions have come from scholars who realized the importance of translating economic concepts into practical rules and analytical techniques that courts and enforcement agencies could apply successfully. ${ }^{111}$

\section{Pressures for Expanding the Enforcement Agenda}

As argued above, the commencement of cases, rather than the actual ability of an agency to execute the matters skillfully, has counted too much in the assessment of agency performance. This enforcement norm is one of multiple forces that press toward more extensive enforcement. In recent years, an increasing number of parties also have pushed hard for expansions of antitrust. Included in the group are certain businesses. There was once a general impression that

110 For example, in Fruehauf, the Second Circuit held that the Commission's finding was based on "speculation rather than fact" and that its legal conclusion was a "non sequitur" that "flies in the face of undisputed contrary evidence." Fruehauf Corp. v. FTC, 603 F.2d 345, 355, 359 (2d Cir. 1979).

111 See William Blumenthal, Clear Agency Guidelines: Lessons from 1982, 68 ANTITRUST L.J. 5, 19-20 (2000) (discussing importance of administrability to success of DOJ 1982 Merger Guidelines); William E. Kovacic, The Influence of Economics on Antitrust Law, 30 ECON. INQUIRY 294, 298-99 (1992) (describing influence of economically sophisticated commentators who distilled economic concepts into operational legal rules). 
business generally favored limited rather than expanded enforcement. Nevertheless, many businesses have since found that use of the government, rather than the market, can assure them success against their competitors, actual or potential. It was perhaps inevitable that this activity - called "rent seeking" by economists - would spread to antitrust. And so it has. During the last decade, prominent antitrust lawyers - including some who earlier had made major contributions in support of the new economic learning - increasingly have undertaken the representation of firms seeking to block or restructure transactions of their competitors. Although competitors can occasionally provide useful information to the government, particularly in Section 2 cases, this development poses a considerable danger for antitrust's future. Given that extensive incentives for expanded enforcement already exist, it threatens to nudge antitrust back to an emphasis on the welfare of individual competitors rather than the welfare of consumers.

The current state of modern industrial organization economics contributes to the ability of the rent seekers to campaign for ever greater use of antitrust. One can find theoretical support for virtually any case in some aspect of modern I.O. ${ }^{112}$ Because this literature largely lacks the empirical support necessary for sound antitrust policy and because it rarely allows courts and agencies to develop workable rules to guide enforcement and business conduct, the impact on antitrust has so far been minimal.

There are still a few commentators who wish to expand enforcement in ways that would retard the progression in recent decades toward sensible substantive and institutional norms. ${ }^{113}$

112 See Timothy J. Muris, Chairman, Federal Trade Commission, Improving the Economic Foundations of Competition Policy, Remarks at the George Mason University Law Review's Winter Antitrust Symposium, Washington, D.C. (Jan. 15, 2003), available at, $\langle$ http://www.ftc.gov/speeches/muris/improveconfoundatio.htm〉.

113 There is now even an organization dedicated to that end, the American Antitrust 48 
Recommended areas of expansion include fuller use of per se rules, ${ }^{114}$ a return to 1970 s' style attacks on distributional restraints, ${ }^{115}$ greater reliance on structural presumptions against mergers, ${ }^{116}$ resurrection of the incipiency doctrine in merger cases, ${ }^{117}$ unprecedented expansion of alleged monopsony in merger cases, ${ }^{118}$ more emphasis on condemning price cutting, ${ }^{119}$ and even a return to the use of non-economic values in antitrust decision making. ${ }^{120}$

Of course, there also are those who argue against modern antitrust or any antitrust at

Institute (AAI). The group's leaders, who have authored the material cited in the remainder of this paragraph, call for enforcement that would disregard the prudent limitations observed in recent decades.

114 Brief of Amicus Curiae American Antitrust Institute, In Support of PlaintiffsAppellees Urging Affirmance of the Grant of Partial Summary Judgment in Favor of Plaintiffs, Abbott Labs, Geneva Pharms., Inc. v. Louisana Wholesale Drug Co., Inc., Case No. 02-12091-J (11 ${ }^{\text {th }}$ Cir. 2002), available at <http://www.antitrustinstitute.org/recent2/193.pdf $>$.

115 See, e.g., Warren S. Grimes, GTE Sylvania and the Future of Vertical Restraints Law, reprinted from ANTITRUST magazine (Fall 2002), available at <http://www.antitrustinstitute.org/recent2/224a.pdf $>$.

116 Warren S. Grimes \& John E. Ewoka, A Study in Merger Enforcement Transparency: The FTC's Ocean Cruise Decision and the Presumption Governing High Concentration Mergers, THEANTITRUSTSOURCE (May 2003), available at <http://www.abanet.org/antitrust/source/may03/grimes.pdf $>$.

117 Robert H. Lande, Resurrecting Incipiency: From Von's Grocery to Consumer Choice, 68 ANTITRUST L.J. 875 (2001).

118 American Antitrust Institute, AAI Comment on the Wal-Mart Merger with Amigo Supermarkets in Puerto Rico (Dec. 20, 2002), available at <http://www.ftc.gov/os/comments/walmart/aai.pdf>; Bert Foer, President, American Antitrust Institute, The American Antitrust Institute: The First Five Years of a Virtual Public Interest Network (Oct. 13, 2003), available at $\langle$ http://www.antitrustinstitute.org/recent2/275.pdf $>$.

120 Norman Hawker, Remarks on an Ethical Perspective of Antitrust Law, Before the Antitrust Task Force of the National Association of Attorneys General, Washington, D.C. (Oct. 1, 2003), available at <http://www.antitrustinstitute.org/recent2/227.pdf.> 
all. ${ }^{121}$ Such arguments have existed for decades, and enforcement officials have no trouble ignoring them.

\section{Accounting Correctly for Non-Litigation Capabilities}

A sound view of competition policy requires enforcement officials not only to identify their appropriate substantive priorities, but also to decide how to accomplish the agency's substantive ends. ${ }^{122}$ The FTC has become more proficient over time in applying its collection of policy instruments in a systematic, coordinated way to accomplish its substantial aims.

Examples include the FTC's work in the pharmaceuticals sector, such as studies, ${ }^{123}$ advocacy, ${ }^{124}$ and litigation, ${ }^{125}$ and the Commission's initiatives to address government restraints on competition, which include litigation, ${ }^{126}$ workshops, ${ }^{127}$ studies, ${ }^{128}$ and advocacy. ${ }^{129}$ The agency

121 Dominick T. ARmentano, Antitrust And Monopoly: AnAtomy OF a Policy FAILURE ( $2^{\text {nd }}$ ed. 1990); Holman Jenkins, FTC Screams for Antitrust W ALL ST. J., Mar. 12, 2003, at A19.

122 See Timothy J. Muris, Looking Forward: The Federal Trade Commission and the Future Development of U.S. Competition Policy2003 C OLUM. BuS. L. REV. 359, 363.

123 See, e.g., See Federal Trade Commission, Generic Drug Entry Prior to Patent Expiration: An FTC Study (July 2002), available at <http://www.ftc.gov/os/2002/07/genericdrugstudy.pdf $>$.

124 Brief of Amicus Curiae Federal Trade Commission, In Opposition to Defendant's Motion to Dismiss, In re Buspirone Antitrust Litigation, 185 F. Supp. 2d 363, 370 (S.D.N.Y. 2002), available at $<$ http://www.ftc.gov/os/2002/01/busparbrief.pdf $>$.

125 See, e.g., Bristol-Myers-Squibb Co., FTC File Nos. 0010221 (Taxol), 0110046 (BuSpar), 021081 (Cisplatin) (Apr. 18, 2003) (consent order), available at <http://www.ftc.gov/os/2003/03/bristolmyersconsent.pdf $>$.

126 See, e.g., South Carolina State Board of Dentistry, Dkt. No. 9311 (Sept. 12, 2003) (complaint), available at <http://www.ftc.gov/os/2003/09/socodentistcomp.pdf > .

127 See, e.g., Notice of Public Workshop and Opportunity to Comment, 67 Fed. Reg. 
should always press itself to consider both its substantive goals and the tools available to achieve its ends.

One of former FTC Chairman Robert Pitofsky's keenest insights was his rediscovery of hearings and workshops as policymaking instruments. The FTC continues to use the intuition that moved Chairman Pitofsky to hold hearings and issue reports to realize the FTC's institutional comparative advantage. The agency is also expanding reliance on administrative litigation ${ }^{130}$ and devoting considerable attention to seeking synergies and policy lessons in the integration of its competition and consumer policies. ${ }^{131}$

A full assessment and application of institutional capabilities provides a more complete insight into the causes of competitive distortions. Consider the case of supplier collusion and facilitating practices. Originating with George Stigler's research on coordination among

48,472 (Jul. 24, 2002). The workshop agenda, the participants' written statements, and public submissions are available at $<$ http://www.ftc.gov/opp/ecommerce/anticompetitive/index.htm>.

128

See, e.g., FTC Staff Report, Possible Anticompetitive Barriers to E-Commerce: Wine (July 2003), available at <http://www.ftc.gov/os/2003/07/winereport2.pdf>.; Alan E. Wiseman \& Jerry Ellig, How Many Bottles Make a Case Against Prohibition? Online Wine and Virginia's Direct Shipment Ban, (Working Paper Mar. 2003), available at 〈http://www.ftc.gov/be/workpapers/wp258.pdf>.

129 See, e.g., Letter from the FTC and the Department of Justice, Comments on the American Bar Association's Proposed Model Definition of the Practice of Law (Dec. 20, 2002), available at <http://www.ftc.gov/opa/2002/12/lettertoaba.htm>; Letter from Charles A. James and Timothy J. Muris to the Ethics Committee of the North Carolina Bar Re: North Carolina State Bar Opinions Restricting Involvement of Non-Attorneys in Real Estate Closings and Refinancing Transactions (Dec. 14, 2001), available at 〈http://www.ftc.gov/be/VO20006.htm>.

130 See, e.g., Chicago Bridge \& Iron Co., Dkt. No. 9300 (Dec. 19, 2003) (interim final order), available at http://www.ftc.gov/os/adjpro/d9300/040102interimconsentorder.pdf.>

131 See, e.g., FTC Staff Report, Possible Anticompetitive Barriers to E-Commerce: Contact Lenses (Mar. 2004), available at <http://www.ftc.gov/os/>. 
competitors, ${ }^{132}$ we understand that suppliers must take several steps to collude effectively: reach consensus on terms of their collaboration, detect cheating, punish cheaters, and cope with entry. One way for a competition agency to attack collusion is to chose policy approaches that make it harder for firms to perform each of these tasks.

A great deal of attention has been devoted to "facilitating practices." One approach that the agencies used to address this was litigation at the fringes of Section 1 doctrine. ${ }^{133}$ There is another way to conceptualize the problem. One phenomenon that facilitates collusion is government regulation and legislation that curbs entry or the forms of competition. Agency advocacy to remove artificial barriers to entry and competition are every bit as valuable to an anti-collusion program as bringing cases.

A proper understanding of what causes or contributes to trade restraints is necessary to decide how best to allocate resources. The Reagan administration implemented a substantial "facilitating practices" agenda that continues today - in the form of challenging (sometimes by litigation, sometimes by advocacy) government restrictions that either impose cartel terms or make cartel coordination easier to achieve. Focusing on the fuller dimensions of the collusion problem - not simply through the lens of litigation - provided a better understanding of what competition policy must do to combat collusion.

\section{The Cumulative Nature of Enforcement}

Enforcement success in any one period often draws heavily upon earlier contributions of the enforcement agencies. For example, DOJ's achievements in criminal enforcement in the 1990s were remarkable, recovering unprecedented sums for injury to the domestic market. The

See George Stigler, A Theory of Oligopoly, 72 J. PoL. ECON. 44 (1964). 
successful prosecution of the food additives and vitamins cartels captured the attention of the world's competition community and catalyzed a global trend of national and regional efforts to detect and punish supplier collusion. The high profile DOJ criminal matters of the 1990s have accelerated the development of comprehensive global efforts to oppose cartels.

Careful examination reveals that the impressive breakthroughs of the 1990s built upon contributions that began in the 1950s and grew through the subsequent decades. ${ }^{134}$ In the midto late-1970s, the DOJ urged courts to apply the recently enhanced penalties and to imprison violators. The Reagan administration pressed for increases in statutory sanctions and prison terms. In 1984, Congress created a new mechanism for calculating criminal fines that permits the maximum Sherman Act fine to be set at twice the loss suffered by victims or twice the offender's gain. ${ }^{135}$ This double loss/double-gain mechanism supplied the basis for the huge recoveries in the 1990s. ${ }^{136}$ The enhancement in penalties continued, with changes to sentencing guidelines and increases in fines. ${ }^{137}$ The development of federal criminal antitrust enforcement reveals progressive, cumulative development of competition policy. DOJ's criminal

133 E.I. du Pont de Demours \& Co. v. FTC, 729 F. 2d 128 (2d Cir. 1984).

134 See Kovacic, Modern Evolution, supra note 4, at 418 (describing successful prosecutions in electrical equipment cases in 1950s and 60s, and the change in Sherman Act criminal violation from misdemeanor to felony and increase in penalties in 1974).

13518 U.S.C. $\$ \S 3571(d)$ (1994). Congress first enacted this provision in the Criminal Fine Enforcement Act of 1984, Pub. L. No. 98-596, 98 Stat. 3134 (1984), and reenacted the measure in the Criminal Fine Improvements Act of 1987, Pub.L.No. 100-185, 101 Stat. 1279 (1987).

136 See Donald I. Klawiter, After the Deluge: The Powerful Effect of Substantial Criminal Fines, Imprisonment, and Other Penalties in the Age of International Cartel Enforcement, 69 GEO. WAS. L. REV. 745 (2001) (discussing impact of double the loss, double the gain fine calculation formula). 
enforcement program has completed each decade in stronger condition than at the decade's start.

The cumulative nature of competition policy requires that each enforcement official recognize the contributions of predecessors and understand how choices today affect performance in the long term. It is a Washington aphorism that policy makers pick the lowhanging fruit. It is less common to hear exhortations about the need to plant trees. Without a norm that accounts for long-term effects of current decisions, incumbent officials may be tempted to invest too heavily in activities that result in immediate opportunities for credit. Those who have observed the evolution of the FTC over 30 years should appreciate the need to invest in the long-term.

\section{Experimentation: Extensions of Policy and Self-Limiting Principles}

Modern experience shows that competition agencies periodically experiment at the boundaries of doctrine - either seeking extensions or exercising restraint. Donald Turner's 1968 Guidelines began the rationalization of merger policy, which was becoming completely detached from any sound conception of economics. ${ }^{138}$ Though modest in retrospect, Turner's self-limiting guidelines were revolutionary when adopted. They not only refused to push enforcement policy to the limits the courts had established, they also established the idea that antitrust officials should issue guidelines that reveal their enforcement intentions, even if this reduced their freedom of action.

When the Reagan administration began, antitrust law was already changing. As a Washington Post editorial later observed, many of the old rules simply were "undermined by

137 See, e.g., Kovacic, Modern Evolution, supra note 4, at 419.

138 U.S. Department of Justice, Merger Guidelines (1968), reprinted irt Trade Reg. Rep. (CCH) II 13,101. 
observations of how the world works." ${ }^{139}$ These changes influenced federal antitrust enforcement. The FTC and the DOJ retreated from enforcement policies based on the simple market concentration doctrine. Reagan officials argued that the earlier period's preoccupation with concentration ratios and suspicion toward benign or procompetitive business conduct led to unduly restrictive merger policies and a record of misconceived monopolization suits. ${ }^{140}$ To chart a new course, the Reagan antitrust era undertook changes to address the previous errors.

As discussed above, the previous antitrust enforcement agenda sprung from two synergistic beliefs about markets. First, a lack of confidence in the power and vitality of markets, and second, overconfidence in government's ability to intervene in markets to fix their perceived weaknesses. The Reagan antitrust agencies held very different beliefs, having great respect for the strength and adaptability of markets and a humble view of their ability to intervene in markets beneficially. Rigid reliance on concentration statistics and structural presumptions would no longer suffice; enforcers would have to study the competitive dynamics of the market. There was growing awareness that the U.S. is part of a global economy and that efficiencies are important. Thus, the Reagan officials sought to apply more sensible merger standards and to withdraw the government from most Section 2 enforcement. ${ }^{141}$

A few FTC activities during the 1970s evidence a re-evaluation of certain types of antitrust enforcement. For example, as Table 1 reveals, the Commission decreased Robinson-

Editorial, WASH. POST, Dec. 27, 1983, at A-16.

140 See William E. Kovacic, Built to Last? The Antitrust Legacy of the Reagan Administration, 35 FED. B. NEWs \& J. 244, 245-46 (1988); William E. Kovacic, Public Choice and the Public Interest: Federal Trade Commission Antitrust Enforcement During the Reagan Administration, 33 ANTITRUST BuLl. 467, 477-78 (1988).

141 See Kovacic, Legacy, 35 FED. B. NEWS \& J, supra note 140, at 245-46. 
Patman Act enforcement. Although there was no statutory change in the Robinson Patman Act to account for this reduction in enforcement, several phenomena likely caused this change, including judicial decisions indicating that courts were becoming increasingly skeptical about the statute.

Another illustration of change is the FTC's assessment of the GM-Toyota joint venture to build subcompact cars in California. The Commission's extensive investigation of the venture was important, both for its impact on automobile producers and consumers and in guiding later thinking about efficiencies and joint ventures. Because the venture, if upgraded beyond its planned scope, could have presented risks to competition, but also would in other respects significantly benefit consumers, the Commission negotiated a consent agreement permitting the venture with certain limitations. As constrained by the consent, the venture 1) increased the total number of small cars for sale in the U.S., thus allowing consumers a greater choice at lower prices; 2) resulted in a car less costly to produce than if GM had to rely on some other production source; 3) offered a valuable opportunity for GM and U.S. industry generally to learn about Japanese manufacturing and management techniques; and 4) enabled Toyota to gain experience with auto manufacturing in the United States before it opened its own plant in Kentucky.

The Commission's decision on the GM-Toyota joint venture seemed daring at the time and was vigorously opposed. One Commissioner dissented bitterly:

In this decision, the Commission has swept another set of generally recognized antitrust principles into the dustbin, using again the incorporeal economic rhetoric that now dominates Commission decision-making. In this case, the decision results in the blessing of a business proposal that is both breathtaking in its audacity and mind-numbing in its implications for future joint ventures leading U.S. firms and major foreign competitors that seek to lend a helping 
hand. $^{142}$

These concerns seem quaint today. Indeed, less than ten years later when the parties argued that there was no longer any reason for the consent order, the Commission agreed. ${ }^{143}$ The antitrust world barely noticed.

\section{E. Articulating a Positive Agenda}

Modern competition policy teaches an important lesson about what competition authorities must do to develop support for their programs. They must work continuously to articulate a positive agenda and to state the assumptions that guide the formulation of the agenda. ${ }^{144}$ Thus, it is useful for agency officials to discuss in detail what the FTC should do in each area of is mandate - competition policy ${ }^{145}$ consumer protection, ${ }^{146}$ and the integration of economic analysis into public policy. ${ }^{147}$

142 General Motors Corp., 103 F.T.C. 374, 397 (1984) (dissenting statement of Commissioner Patricia P. Bailey).

143 General Motors Corp., 116 F.T.C. 1276 (1993).

144 See Richard A. Harris \& Sidney M. Miklis, The Politics of Regulatory CHANGE 187-89 (2d ed. 1996) (emphasizing that James C. Miller III's contributions to regulatory reform as FTC Chairman consisted substantially of building and implementing a positive agenda rather than simply rolling back unsound policies that he inherited).

See, e.g., Muris, Looking Forward, supra note 122, at 359.

146 See, e.g., Timothy J. Muris,, Chairman, Federal Trade Commission, The Federal Trade Commission and the Future Development of U.S. Consumer Protection Policy, Remarks at the Aspen Summit (Aug. 19, 2003), available at <http://www.ftc.gov/speeches/muris/030819aspen.htm>.

147 See, e.g., Timothy J. Muris, Chairman, Federal Trade Commission, Improving the Economic Foundations of Competition Policy, Remarks at the George Mason University Law Review's Winter Antitrust Symposium, Washington, D.C. (Jan. 15, 2003), available at, 
Past experience underscores the importance of these measures. A key element of Jim Miller's chairmanship of the FTC was to explain the affirmative steps the agency was committed to accomplish - for example, the prosecution of collusive behavior, especially in the professions, on the competition side, and the prosecution of serious fraud on the consumer protection side and not simply to indicate areas in which it would retreat. Unfortunately, some officials in the FTC and in the DOJ lost sight of this principle in Ronald Reagan's second term.

\section{H. Anticipating and Accounting for Institutional Change}

The past four decades have featured extraordinary change in the institutions that influence competition policy. One major phenomenon is the greater distribution of policymaking authority - at home and abroad. New competition policy bodies now exist, and existing bodies have assumed expanded policymaking roles. Another change is a growing awareness of how the interaction of seemingly distinct institutions affects competition policy. As the FTC's recent report on intellectual property reveals, one may not routinely think of rights granting organizations as formulating competition policy, but they greatly influence the competitive environment. $^{148}$

Both dimensions - the greater distribution of authority and an understanding of the interaction of institutions - require reassessment of the choice of policy tools, the approaches to reconciling the operation of different agencies, and the selection of strategies for dealing with institutional multiplicity. Two lessons from the history of modern competition policy and from the evolution of other fields of law stand out.

<http://www.ftc.gov/speeches/muris/improveconfoundatio.htm>.

148 Federal Trade Commission, To Promote Innovation: The Proper Balance of Competition and Patent Law and Policy 2 (Oct. 2003), available at <http://www.ftc.gov/os/2003/10/innovationrpt.pdf >. 
The first lesson is to appreciate the need to develop approaches for ensuring that the best ideas emerge to guide policymaking. Thus, investments in activities that promote the "bottomup" development of norms can yield superior, widely accepted standards. ${ }^{149}$ This explains the emphasis the agency has given to the International Competition Network and to encouraging fuller cooperation with domestic agencies that influence competition policy.

The second lesson is the need to watch for opportunities to identify superior approaches and to formulate cooperative relationships to improve upon the results that any single competition body could achieve. Thus, U.S. competition policy officials can benefit greatly from studying the accomplishments and experience of their colleagues in Europe. ${ }^{150}$ FTC officials also have underscored their interest in working with other U.S. institutions to formulate a positive cooperative program that improves the overall quality of U.S. competition policy. ${ }^{151}$

\section{Improving the Institutional Foundations for Competition Policy}

Modern competition policy experience contains lessons for how competition agencies should operate. This section uses those lessons to identify several steps to improve the quality of competition policy.

149

See Timothy J. Muris, Chairman, Federal Trade Commission, Competition Agencies in a Market-Based Global Economy, Remarks at the Annual Lecture of the European Foreign Affairs Review, Brussels, Belgium (July, 23 2002), available at 〈http://www.ftc.gov/speeches/muris/020723brussels.htm〉.

150 See Timothy J. Muris, Chairman, Federal Trade Commission, State Intervention / State Action - A U.S. Perspective, Remarks Before the Fordham Annual Conference on International Antitrust Law \& Policy, New York, NY (Oct. 24, 2003), available at $\langle$ http://www.ftc.gov/speeches/muris/fordham031024.pdf〉.

151 See Susan A. Creighton, Director, Bureau of Competition, Federal Trade Commission, A Federal-State Partnership on Competition Policy: State Attorneys General as Advocates, Remarks Before the National Association of Attorneys General 2003 Antitrust Seminar, Washington, D.C. (Oct. 1, 2003), available at <http://www.ftc.gov/speeches/other/ 


\section{A. Continuing Self-Assessment}

To sail on an accurate course, one cannot merely point the ship in what one believes to be the right direction. Good navigation requires periodic readings to verify that the ship is still on course. Relying on a single, isolated reading is insufficient; constant verification is required. Only repeated checking of progress and comparisons of an array of indicators will keep the ship from substantial deviations.

For competition policy agencies, this insight requires continuing investments in analyzing the consequences of what they do, both with litigation and with non-litigation tools. For example, to assess the efficacy of merger enforcement, agencies should analyze the effects of past enforcement actions, including non-enforcement decisions. They need to understand better the industry and firm specific conditions relevant to the potential for anticompetitive effects. They also require more knowledge about the nature and likelihood of significant procompetitive effects of mergers. Understanding the efficiencies that can arise from mergers and how they are achieved would provide greater ability to evaluate prospective mergers.

Embracing a norm of self-assessment - for example, by studying the effects of past initiatives - serves multiple ends. Perhaps most important, it helps avoid being trapped in an analytical model that developments in theory and doctrine have passed by. Since the 1970s and the structure-conduct-performance debate, the number of industrial organization (I.O.) economists and their research have soared. During the 1980s and into the 1990s, industrial organization attracted many of the best young economists. Although I.O. was once a largely empirical discipline, in recent decades empirical research has lost much of its market share. The lure of I.O. for most young economists was to apply modern mathematical economics (largely 
game theory) to the relatively undeveloped turf of industrial organization.

Undoubtedly, there have been important advances in this mathematical literature that have been distilled into useful operational principles. For example, modern oligopoly theory built on the work of George Stigler to provide a useful approach to the analysis of tacit coordination. The enhancement by DOJ and other competition authorities of leniency programs employs the basic intuition of the prisoner's dilemma to induce individual cartel participants to reveal their unlawful collaboration. Despite these accomplishments, there have been few successful efforts to translate the mathematically elaborate, game theoretic models into administrable antitrust rules or analytical techniques to support enforcement.

\section{B. Competition Policy R\&D}

Performing ex post assessments of agency initiatives is one dimension of a larger category of activity that one can call competition policy R\&D. ${ }^{152}$ Using workshops, hearings, studies, and reports, the agency increases its intellectual capital and informs the competition policy community about noteworthy developments. Investments in competition policy R\&D are assuming progressively greater importance. In a world of greater economic complexity and institutional multiplicity, building intellectual capital is essential to understand new phenomena and to exercise intellectual leadership. With broadly distributed policymaking authority, the FTC typically cannot impose its will on other competition agencies. It must gain acceptance for its views by persuasion, not fiat. Without strong intellectual capital, such persuasion is impossible.

\section{Accounting for Long-Term Institutional Effects}

152 See Muris, Future Development of Competition Policy, supra note 122, at 403404. 
Past experience compels one to inquire how today's policy choices affect tomorrow's competition policy. Is the agency managing its resources to the greatest effect or is it overcommitted? Before the agency undertakes new projects, it needs to determine whether it can see them through to completion. Should the agency test prototypes of initiatives on a limited scale before undertaking full production?

A vital focus of decision making should be how individual resource allocation choices contribute to the long-term success of the agency. History shows how the decisions of any FTC chairman affect the agency's performance for years after the incumbent chairman leaves office. Agency leaders must resist the temptation of eliciting the transient praise that comes from starting projects that look good on take-off but run a serious risk of crashing during a successor's tenure. The goal is to make choices that generate positive, not negative, externalities on the agency and future leadership.

\section{Conclusion}

As the interval between the events described in this paper and the current time increases, it is likely that a growing part of antitrust community, here and abroad, lacks first-hand knowledge of much of this history. An attorney who began a career in 1980 would have little direct experience with enforcement in the 1960s or 1970s. If that attorney started in 1990, he or she would have heard of Bill Baxter or Jim Miller but would not have observed the adjustments they or other Reagan appointees brought to federal enforcement. If the attorney began work in the past few years, a common condition in the many jurisdictions that only recently have adopted competition laws, most of this history comes second hand. Indeed, sometime in the near future, a generation of leadership will come to the world's antitrust agencies without first-hand familiarity with the developments that shaped competition policy in the last decades of the $20^{\text {th }}$ 
century.

In the past few years, the FTC has devoted considerable attention to the historical evolution of competition policy. In 2001, the agency convened a program to recognize the $25^{\text {th }}$ anniversary of the enactment of the Hart-Scott-Rodino Antitrust Improvements Act of 1976. In the same year, the Commission inaugurated the Miles W. Kirkpatrick Award for outstanding service to the Commission. The first three recipients were Basil Mezines, Robert Pitofsky, and Jodie Bernstein. In 2003, the Commission held a day-long symposium on economic analysis to commemorate the $100^{\text {th }}$ anniversary of the creation of the FTC's predecessor body, the Bureau of Corporations. $^{153}$

These and similar activities serve multiple purposes. One basic and important aim is to honor the many individuals who have built the Federal Trade Commission. This paper has described good policy as partly the result of a cumulative development over time. Great public institutions remember and respect those who made the farsighted investments to make the progression possible. Recounting this history is forward-looking, as well. With the gradual thinning of the ranks of individuals who witnessed antitrust's modern development firsthand, there is an urgency to see that the competition policy community and new agency leaders understand past experience. Strong policymaking builds upon accurate knowledge of past enforcement trends and a sound interpretation of intellectual and institutional forces that account for changes in emphasis and activity over time. So it is that history should, and does, inform practice.

153 See FTC Announces Roundtable Celebrating 100th Anniversary of its Predecessor Agency - the Bureau of Corporations (July 2003), available at <http://www.ftc.gov/opa/2003/07/beroundtable.htm.> 